
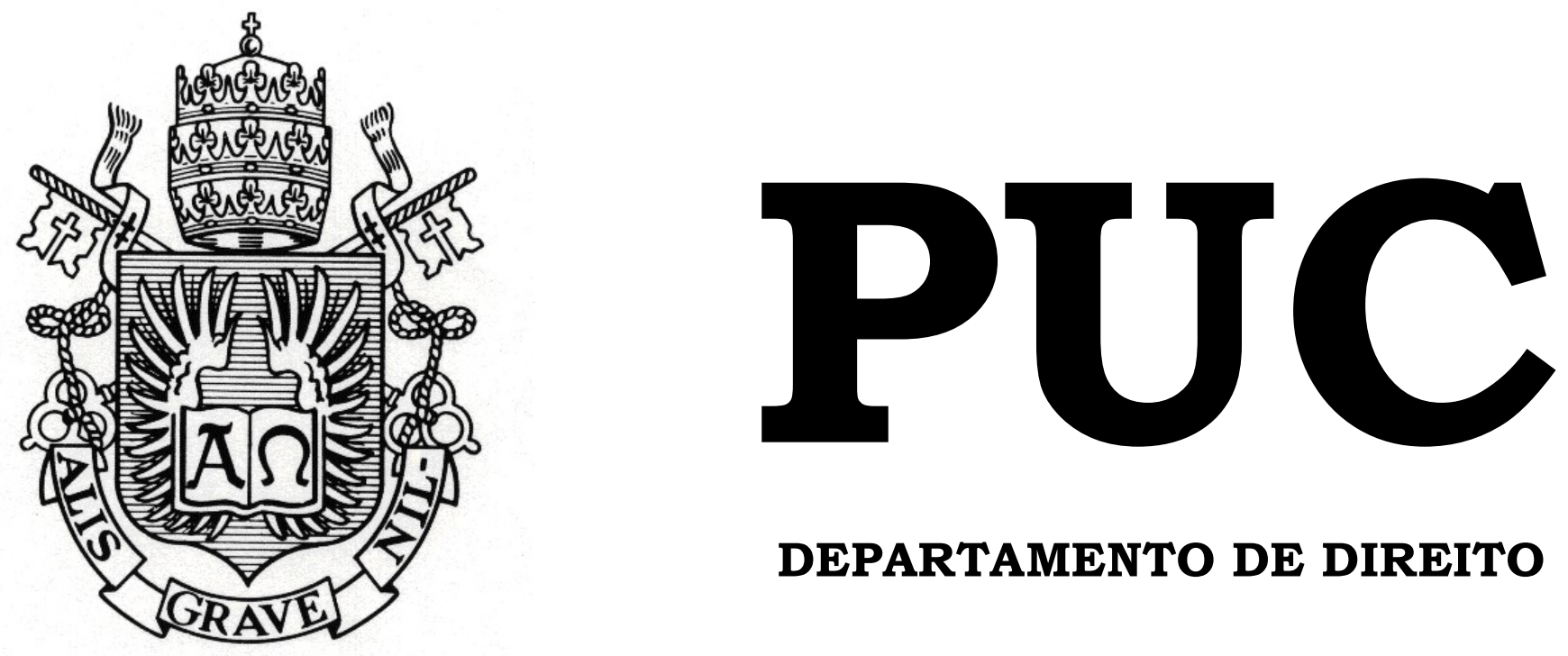

DEPARTAMENTO DE DIREITO

\title{
A PUNIBILIDADE DO INSIDER TRADING NO DIREITO BRASILEIRO
}

por

GIOVANNA MARCHETTI DE AZEREDO LOPES CORRÊA

ORIENTADOR: Francisco Antunes Maciel Müssnich

2016.1

PONTIFÍCIA UNIVERSIDADE CATÓLICA DO RIO DE JANEIRO

RUA MARQUÊS DE SÃO VICENTE, 225 - CEP 22453-900

RIO DE JANEIRO - BRASIL 


\title{
A PUNIBILIDADE DO INSIDER TRADING NO DIREITO BRASILEIRO
}

\author{
por \\ GIOVANNA MARCHETTI DE AZEREDO LOPES CORRÊA
}

Monografia apresentada ao

Departamento de Direito da

Pontificia Universidade Católica do Rio de Janeiro (PUC-Rio) para a obtenção do Título de Bacharel em Direito.

Orientador: Francisco Antunes Maciel Müssnich 


\section{Dedicatória}

Aos meus pais, por todas oportunidades que sempre me deram. 


\section{Agradecimentos}

Gostaria de agradecer à minha família, especialmente meus pais por todo carinho e amor, por me ensinarem o valor da dedicação e do estudo e terem certeza do meu sucesso.

Ao Diogo, por estar ao meu lado durante todo este tempo, me dando apoio, suporte, incentivo e torcendo tanto por minha felicidade.

Ao meu orientador, Chico Müssnich, pela inspiração profissional, pela ajuda e aconselhamento ao longo da elaboração desse trabalho, bem como a todos meus amigos do Escritório Barbosa, Müssnich e Aragão, em especial aos queridos Juliana, Fernanda, Ana Paula e Bruno, responsáveis por todo meu aprendizado em direito societário e por minha formação como advogada.

Às queridas Eduarda e Thamires, obrigada por me escutarem, ajudarem e dividirem seus dias, noites e risadas comigo.

A todos meus professores e amigos da PUC - Rio que fizeram com que esses cinco anos fossem tão ricos e prazerosos. 


\section{Resumo}

O presente trabalho tem como objetivo principal analisar a utilização de informações privilegiadas no mercado de valores mobiliários brasileiro, identificando os principais aspectos do ilícito amplamente combatido em diversos países do mundo. Para o desenvolvimento do tema foi necessária uma breve exposição do princípio do full disclosure e do dever de informar, que são duas das principais formas de repressão ao ilícito de insider trading. Ao longo do trabalho identificam-se as diferenças entre a regulação da CVM e a Lei das Sociedades Anônimas, abordando o elemento subjetivo da prática do insider, a necessidade de auferir vantagem. Apresenta-se ainda diferenças entre as espécies de insider, os insiders primários, os secundários, ou de mercado, e o temporário, bem como os elementos para sua caracterização. Por fim, são apresentados importantes casos julgados pela CVM, que contribuíram para o desenvolvimento da repressão à prática de insider trading no Brasil.

\section{Palavras-chave}

Insider Trading - Informação Privilegiada - Princípio do Full Disclosure - Lei das Sociedades Anônimas - Comissão de Valores Mobiliários - Dever de Informar - Insider Primário - Insider Secundário - Insider Temporário - Responsabilidade. 


\section{Sumário}

INTRODUÇÃO ........................................................................................................................... 8

1. DIREITO À INFORMAÇÃO NO MERCADO DE CAPITAIS .................................... 12

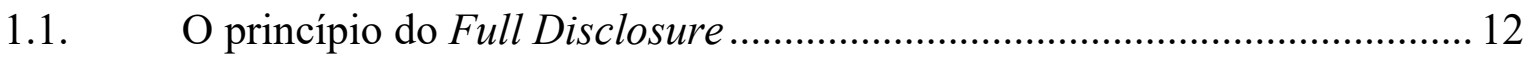

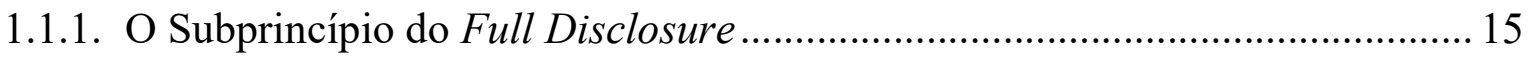

1.2. Direito à Informação no Mercado de Capitais............................................ 17

2. O Elemento SubJetivo No InSIDER TRADING BRASILEIRO......................... 21

2.1. Necessidade de auferir vantagem? .................................................... 21

2.2. Diferenças entre a Lei das Sociedades Anônimas e a Instrução da CVM .. 27

2.3. Inversão do ônus da prova, solução pacífica ........................................... 35

3. A Punibilidade do Insider Trading no Direito Brasileiro .................... 40

3.1. Diferenças entre prova indiciária e indício no Insider Trading .................. 40

3.2. Diferenças entre a punibilidade insider primário, insider secundário ou

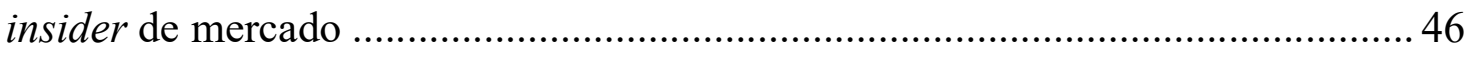

3.2.1. Insider primário, o elemento subjetivo do art. 13 da Instrução CVM nº 358/02, indícios e presunções ............................................................................. 53

3.2.2. Insider de mercado e a prova indiciária...................................................... 57

4. JULGADOS DA CVM SOBRE O TEMA ........................................................60

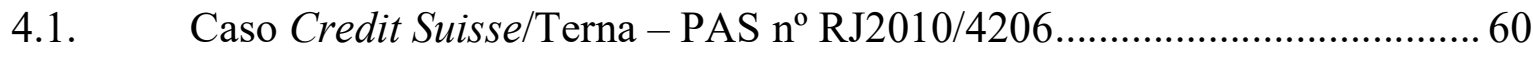

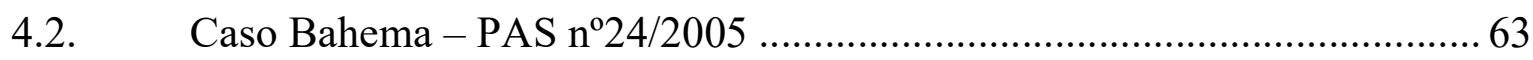

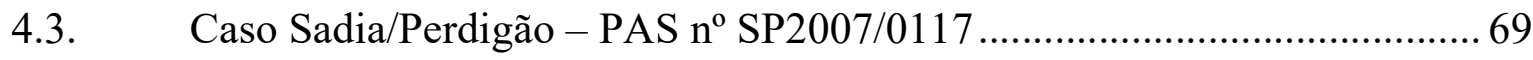


4.4. Caso Eletropaulo - PAS n $\quad$ C4/04

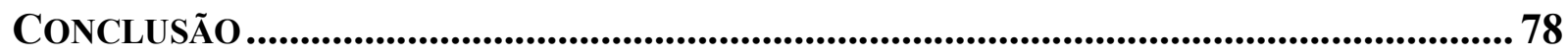

REFERÊNCIAS BIBLIOGRÁFICAS........................................................................ 81 


\section{Lista de Abreviações}

$\begin{array}{ll}\text { CVM } & \text { Comissão de Valores Mobiliários } \\ \text { BACEN } & \text { Banco Central do Brasil } \\ \text { Lei das S/A } & \text { Lei } 6.404 \text { de 1976 } \\ \text { SEC } & \text { Securities and Exchange Comission } \\ \text { ADR's } & \text { American Depositary Receipts } \\ \text { NYSE } & \text { Bolsa de Nova Iorque } \\ \text { NCPC } & \text { Novo Código de Processo Civil, Lei }{ }^{\circ} \text { 13.105/15 }\end{array}$




\section{Introdução}

A prática do insider trading é um dos principais ilícitos previstos pela legislação que regulamenta o mercado de capitais. Trata-se do uso de informação privilegiada no âmbito do mercado, regulamentado no Brasil através das leis 6.385/76 e 6.404/76, bem como pela Instrução CVM no 358/02.

O ilícito ocorre no âmbito das companhias abertas, e tem como principal fundamento a atuação dolosa do agente com o objetivo de auferir vantagem para si ou para terceiros, negociando valores mobiliários de uma companhia, com base em uma informação que ainda não está disponível no mercado.

O insider tem como principal requisito a utilização de informações privilegiadas, isto é, informações que não podem, ou que ainda não estão disponíveis ao mercado em geral, por serem, ou não, sigilosas e relevantes, capazes de influenciar a cotação dos valores mobiliários da companhia, principalmente influenciando a decisão do investidor na hora de investir.

Diante da relevância de tais informações e de seu potencial dano ao mercado, o legislador criou medidas de controle à utilização de informações relevantes. O princípio do full disclosure é um deles. Este princípio traduz o dever, principalmente dos administradores, em divulgar informações relevantes sobre seus negócios de forma clara e eficiente, proporcionando a todos os participantes do mercado igualdade no acesso às informações.

Tratando especificamente sobre o agente do ilícito entende-se que este pode ser qualquer indivíduo que obtenha informações sigilosas sobre os negócios de determinada 
companhia e as utilize para obter vantagem ao negociar no mercado. O insider se divide em três espécies (i) insider primário, (ii) insider secundário e (iii) insider temporário.

Os insiders primários são os administradores ou pessoas a ele equiparadas, acionistas controladores, pessoas de sua confiança, membros do conselho fiscal e demais órgãos criados pelo estatuto social para o assessoramento da administração. Os insiders secundários, por sua vez, são terceiros que não possuem vínculo profissional com a companhia, aqueles que obtêm conhecimento da informação privilegiada por intermédio da administração, por exemplo. Já os insiders temporários são aqueles que, em razão de uma relação profissional, tiveram acesso a informações relativas aos negócios da companhia por um curto período de tempo, como um advogado, auditor ou banqueiro por exemplo.

A prática do insider trading é amplamente combatida no mercado de capitais principalmente por duas razões, uma de aspecto econômico e outra de cunho ético. Quanto ao aspecto econômico, é importante que o mercado reflita os preços das ações com base em um sistema de transparência, no qual todas as informações relevantes devem estar publicamente disponíveis, fato que se consegue por meio da obediência ao princípio do full disclosure. Já, no aspecto ético, há uma preocupação maior com o princípio da igualdade de acesso a informação, que impede a obtenção de lucros mediante utilização de informação privilegiada, obtida antes que se tornasse pública, promovendo um desequilíbrio em relação aos demais participantes do mercado, justamente o que se pretende evitar. 
A partir daí, em 2001, o uso de informação privilegiada que já constituía infração de natureza grave (art.18 da Instrução CVM 358/02), foi tipificado com um ilícito penal pela lei 10.303/01, que introduziu o art. 27-D na lei 6.385/76. É importante ressaltar que, tendo em vista a relevância da matéria no que concerne a proteção do mercado de valores mobiliários, a conduta do agente pode ter consequências no âmbito penal, administrativo e civil.

Com efeito, o Estado intervém na esfera privada do mercado. A busca por um mercado de capitais sadio e transparente só é possível se práticas não equitativas, como o insider trading, forem prevenidas e reprimidas, de forma a contribuir para formação de capital, ligando a poupança pública ao investimento e estimulando cada vez mais o desenvolvimento econômico.

De modo contrário, em um mercado de capitais manipulável, onde atuam agentes que se valem de informações privilegiadas, se sobrepondo ao restante dos investidores em evidente desigualdade, não existe a segurança necessária para fomentar os investimentos e manter a higidez do mercado.

Dito isto, o objetivo do presente trabalho é analisar a matéria de forma ampla, observando as legislações que tratam sobre o tema, identificando suas peculiaridades, e os elementos para caracterização dos diferentes tipos de insider, quais sejam o primário ou clássico, o secundário, comumente chamado de insider de mercado e o insider temporário.

Será demonstrada a importância que as normas que regulam o direito dos acionistas e investidores possuem como forma de controle de repressão da prática do insider trading, incentivando a ampla divulgação de informações, buscando uma maior transparência do mercado de valores mobiliários. 
Dessa forma, também será abordado o princípio do full disclosure que representa o dever de informar, e tem como objetivo evitar uma situação de assimetria informacional entre os participantes do mercado por serem mecanismos de incentivo à divulgação das informações relevantes.

Por fim serão analisados alguns casos importantes julgados pela CVM, que contribuíram para a construção e evolução da legislação brasileira no sentido de coibir a prática de uso da informação privilegiada no âmbito do mercado. 


\section{Direito à Informação no Mercado de Capitais}

\subsection{O Princípio do Full Disclosure}

O princípio do full disclosure pode ser entendido como o princípio da maximização da divulgação de informações por parte dos agentes regulados. Compreende-se sua natureza jurídica como o princípio da transparência no mercado de capitais, visto que se manifesta na especialização do princípio da publicidade, muito importante na relação entre os agentes de mercado.

Suas origens remetem a 1929, com a quebra da Bolsa de Valores de Nova York (NYSE), decorrente de inúmeras fraudes e abusos cometidos, face à ausência de realidade no status financeiro das companhias e dos seus títulos, combinados à falta de padronização e confiabilidade dos relatórios e à excessiva liberdade dos mecanismos privados de negociação de valores mobiliários. As leis estaduais sobre valores, comumente conhecidas como "blue sky laws", não foram suficientes para regular e controlar as bolsas de valores.

\footnotetext{
"The state statutes and rules are commonly referred to as blue-sky-laws. The origin of the phrase 'blue sky' originated on the floor of the Kansas legislature when a state legislator was proposing an antifraud law to 'keep intruders from coming to Kansas to sell our citizens a piece of the blue sky'. A Supreme Court case also used the term in ruling against 'speculative schemes which have no more basis than so many feet of blue sky."1
}

Diante desse cenário de caos econômico, onde o mercado havia perdido seu valor, surge o consenso de que a recuperação dependia da restauração da confiança no mercado de capitais.

${ }^{1}$ MOYE, John E. The law of business organizations, $5^{\mathrm{a}}$ ed., EUA: International Thomson Publishing Company, 1998, p. 259 
Somente a partir da criação dos Securities Acts de 1933 e 1934 é que foi instituído um sistema de negociação de valores mobiliários que reconhece o caráter privado das instituições e negócios jurídicos, mas que lhes impõe ampla divulgação de informações sobre as companhias e os valores emitidos, bem como seu prévio registro junto à autoridade central, foi esse novo modelo de regulação que possibilitou a estabilização do mercado financeiro e lhe devolveu a credibilidade.

Seguindo este contexto, foi introduzida uma nova forma de filosofia da informação, na qual ocorre uma ruptura com a lógica privatista que prevalecia no passado, em benefício de uma disciplina que busca a publicidade de informação, e que devido ao sucesso, foi adotada pelas legislações de vários países.

Diante disso, percebe-se que este é, de fato, o princípio central do direito das sociedades e do mercado de valores mobiliários. Exatamente porque dele decorrem as normas que protegem os investidores que possuem informações, realizam investimentos racionais em títulos, com preços que refletem seus exatos valores, possibilitando que transcorra do mercado a confiança necessária para seu fortalecimento.

Consequentemente, entende-se que as exigências previstas pelas leis e regulamentos, que determinam a transparência de todas as informações sobre fatos relevantes no mercado são a principal forma de proteção aos investidores, isso porque, são elas as responsáveis por validar fundamentadamente as decisões em investimentos, contrabalanceando riscos com recompensas.

A transparência exigida por tais ordenamentos se revela instrumento indispensável à verificação e supervisão dos investimentos, garantindo aos 
investidores meios de compreensão e influência no desempenho e a atuação de sua companhia e de suas aplicações.

Diante disso, os agentes reguladores se esforçam para promover ao máximo a divulgação de informações. Isto é, no aspecto quantitativo exigem a publicação de documentos de prestação de contas, devidamente auditados e bastante detalhados, e no aspecto qualitativo, tornam públicas as decisões de investimentos do mercado, conforme se compreende do trecho abaixo:

"Desta forma, na medida em que a informação divulgada potencia um acréscimo de confiança que está na base da entrada em certo mercado - de outra forma procurar-seia a satisfação de necessidades por vias alternativas -, é a própria dimensão e funcionamento do mercado que dela estão dependentes, com os benefícios daí decorrentes para todos os agentes que nele atuam. Estaríamos, assim, em presença de um verdadeiro 'círculo virtuoso' em que através da existência de informação, em regra a cargo dos oferentes, se tutela, em primeira linha, o interesse geral e objectivo do mercado, e consequentemente, por via indirecta, os interesses dos investidores. Não se trata, pois, de pensar no interesse do investidor em primeiro lugar, mas antes de tutelar o mercado como instrumento de satisfação do interesse geral e, concomitantemente, dos interesses dos agentes que nele atuam."

Não por outra razão, as expectativas do mercado se formam de maneira mais robusta, o que diminui a volatilidade, provocando a regular formação de preços e contribuindo para a estabilidade e o aprofundamento dos laços de confiança existentes entre os agentes no mercado.

E como visto anteriormente, essa confiança é condição básica ao crescimento e existência do mercado, por isso, é essencial que o sentimento de crença na equidade de acesso às informações relevantes se desenvolva.

${ }^{2} \mathrm{PINA}$, Carlos Costa. Dever de informação e responsabilidade pelo prospecto no mercado primário de valores mobiliários, Coimbra : Coimbra Editora, 1999, pp. 28, 29. 


\subsubsection{Subprincípios do Full Disclosure}

Apesar de todo o exposto, o princípio do full disclosure não se encerra apenas na divulgação de uma informação qualquer. $\mathrm{O}$ que o princípio exige é exatamente a publicação da informação relevante.

Diante disso, para facilitar a compreensão do princípio do full disclosure a doutrina o separa em três subprincípios ${ }^{3}$ : (i) relevância, (ii) adequação e (iii) acessibilidade da informação, os quais serão estudados a seguir.

A relevância da informação diz respeito ao objeto da informação. Temse por relevante toda e qualquer informação que ao ingressar no conhecimento do investidor teria a capacidade, real ou potencial, de influenciá-lo em seu julgamento.

Atualmente o conceito de relevante tem se alargado, em função das práticas de boa governança corporativa, que, no que dizem respeito ao full disclosure recomendam a divulgação de informações pelas sociedades anônimas.

Dessa forma deve-se entender que a relevância de um fato se mede pelo grau de influência que ele possa produzir em um investidor sensato.

A adequação da informação por sua vez, diz respeito às exigências de veracidade, objetividade, clareza, oportunidade e completude. Isso porque a

\footnotetext{
${ }^{3}$ MILLER, Daniel Schiavoni. et al. Governança Corporativa e Full Disclosure: O Direito à Informação Como Direito Subjetivo Instrumental, Implicitamente Essencial e Inderrogável do Acionista. In: CANTIDIANO, Luiz Leonardo. (org). Governança Corporativa: empresas transparentes na sociedade de capitais. Lazuli Editora, 2004, p.91-128
} 
informação precisa ser, antes de mais nada, confiável para ser considerada uma informação relevante.

Por outro lado, a acessibilidade da informação determina que não basta que a informação seja relevante e adequada. É necessário que possua acesso livre, pleno e simultâneo para todos. ${ }^{4}$ Aqui está se tratando do polo passivo da informação, de como ela pode ser recebida pelos destinatários.

A própria Instrução da $\mathrm{CVM} \mathrm{n}^{0} 358 / 02$, visando à adequada disseminação da informação relevante, dispõe no caput de seu artigo $5^{\circ}$.

"Art. $5^{\circ}$ A divulgação de ato ou fato relevante deverá ocorrer, sempre que possível, antes do início ou após o encerramento dos negócios nas bolsas de valores e entidades do mercado de balcão organizado em que os valores mobiliários de emissão da companhia sejam admitidos à negociação.

§1o Caso os valores mobiliários de emissão da companhia sejam admitidos à negociação simultânea em mercados de diferentes países, a divulgação do ato ou fato relevante deverá ser feita, sempre que possível, antes do início ou após o encerramento dos negócios em ambos os países, prevalecendo, no caso de incompatibilidade, o horário de funcionamento do mercado brasileiro.

§2o Caso seja imperativo que a divulgação de ato ou fato relevante ocorra durante o horário de negociação, o Diretor de Relações com Investidores poderá, ao comunicar $\mathrm{o}$ ato ou fato relevante, solicitar, sempre simultaneamente às bolsas de valores $\mathrm{e}$ entidades do mercado de balcão organizado, nacionais e estrangeiras, em que os valores mobiliários de emissão da companhia sejam admitidos à negociação, a suspensão da negociação dos valores mobiliários de emissão da companhia aberta, ou a eles referenciados, pelo tempo necessário à adequada disseminação da informação relevante.

§3o A suspensão de negociação a que se refere o parágrafo anterior não será levada a efeito no Brasil enquanto estiver em funcionamento bolsa de valores ou entidade de mercado de balcão organizado de outro país em que os valores mobiliários de emissão da companhia sejam admitidos à negociação, e em tal bolsa de valores ou entidade de mercado de balcão organizado os negócios com aqueles valores mobiliários não estiverem suspensos."

\footnotetext{
${ }^{4}$ Ibid. p. 91-128.

${ }_{5}^{5}$ Instrução CVM 358 de 2002. Disponível em [http://www.cvm.gov.br/legislacao/inst/inst358.html] Acesso em 02.06.2016.
} 
Dessa forma, a informação ainda não divulgada ao mercado é justamente o que precisa ser guardado em sigilo, visto que ela pode gerar uma assimetria. A partir disso define-se que:

"São insiders os administradores, conselheiros e diretores, acionistas controladores, membros do conselho fiscal e de quaisquer órgãos, criados pelo estatuto da companhia, com funções técnicas ou destinadas a aconselhar os administradores, empregados da companhia, além de subordinados e terceiros de confiança e, finalmente, qualquer pessoa que tenha tido acesso a informações relevantes ainda não divulgadas." ${ }^{\prime 6}$

Assim, resta claro que, o princípio da transparência no mercado de capitais é norteador da repressão do insider, como fenômeno de nondisclosure. Ou seja, o full disclosure é medida que assegura aos investidores a acessibilidade, plena e simultânea, às novas informações.

\subsection{Direito à Informação no Mercado de Capitais}

Sob o olhar da simetria de informação, o dever de informar decorre da necessidade de impedir que pessoas, que possuam acesso a informações privilegiadas devido aos cargos que ocupam na estrutura social, beneficiem-se, obtendo vantagem sobre os demais acionistas e investidores no mercado. $\mathrm{O}$ dever de informar serve, exatamente, para estabelecer igualdade informacional entre os investidores para que possam transacionar com certo grau de segurança quanto as informações existentes sobre seus negócios.

Precisamente por isso, o dever de informar e o princípio do full disclosure andam juntos, visto que, o princípio perderia totalmente seu racional, se todos os participantes do mercado não fossem obrigados a fornecer ao público as informações que possuem.

${ }^{6}$ EMERSON, Robert W. e HARDWICKE, John W. Business Law, $3^{\mathrm{a}}$ ed., Barron's Educational Series Inc., 1997, EUA, p. 366. 
A companhia por sua vez, cumpre o dever de informar prestando informações obrigatórias, não obrigatórias, periódicas e eventuais, que dizem respeito a ela e a seus títulos e que vão desde a entrega e a divulgação de relatórios e demonstrações financeiras, a comunicação de fatos relevantes.

Dessa forma, fica claro que o dever de informar, no que se refere as companhias, compreende a gestão e os negócios sociais, as relações entre os órgãos sociais e dirigentes e a sociedade e as relações dos acionistas entre si.

Cabe ainda ressaltar que o full disclosure serve justamente para que o acionista tenha condições de decidir autonomamente sobre um negócio. Isso porque, apenas tendo acesso a todas as informações disponíveis no mercado o acionista poderá avaliar o preço dos valores mobiliários e as condições para alienar estes valores.

Isto posto, entende-se que o direito à informação, ao mesmo tempo, acessório e instrumental dos direitos sociais, é essencial, sob pena de impedir que o acionista tenha pleno seus direitos de participação e fiscalização nas sociedades.

Como vimos, dever de informar precisa ser respeitado pelos administradores, sob pena de responsabilização, para que todos os investidores tenham oportunidades iguais de negociação.

O momento para a efetivação do cumprimento do dever de informar se dá ao final da negociação realizada. Não sendo o caso de negociação, o melhor momento para a comunicação opera-se quando o fato se mostrar irreversível, devendo a comunicação ser imediata pelo surgimento do perigo de vazamento das informações. 


\begin{abstract}
"A informação à BM\&F Bosvespa e publicação (art. 289) deve ser feita no exato momento em que o mercado pode ser influenciado por informações ainda não reveladas ao público.

Logo, a revelação e publicação (art. 289) deve ser imediata, porque, a partir de sua posse sigilosa das informações pelos administradores, o perigo de vazamento surge naturalmente (art. 155).

A retenção de informações até o momento em que essa influência venha a se manifestar, mediante a alteração artificial e específica das cotações e do movimento de liquidez dos valores mobiliários nela negociados, constitui quebra do dever de informação oportuna. Ainda que a informação dada ao mercado, pela Bolsa de Valores, possa vir a estancar os boatos e manipulações daí decorrentes, o dano à reputação da companhia e à própria confiabilidade do mercado já terá ocorrido. Consequentemente, a informação dos fatos relevantes e sua publicação (art. 289) devem ser imediatas." 7
\end{abstract}

Nesse sentido, as informações precisam ser imediatas, precisas e não podem ser falsas, na medida em que se forem mal formuladas podem criar uma falsa impressão, conduzindo os acionistas e os investidores a uma decisão enganosa sobre os fatos prestados.

Seguindo esta mesma lógica, o voto do ex- Diretor da CVM Pedro Oliva Marcilio de Souza na sessão de julgamento do processo PAS RJ 2007/1079:

\begin{abstract}
"No mercado de valores mobiliários, o dever de informar dos administradores é um dever de ser leal com seus acionistas e com o mercado, pois é a partir das informações por eles prestadas que se pode definir o valor das ações (ou de outros valores mobiliários) da companhia. Informações completas e atuais são a base do mercado de valores mobiliários e são essenciais para o funcionamento adequado do mecanismo de preços, que é da essência de qualquer mercado.

A divulgação compulsória de informações pelos administradores de companhias abertas, além de permitir o adequado funcionamento do mecanismo de preços, auxilia uma melhor governança das companhias, na medida que a "repreensão" que os administradores podem vir a sofrer por parte de seus acionistas, de analistas ou, no caso brasileiro, do regulador, ajuda a impedir a tomada de decisões consideradas impróprias." 8
\end{abstract}

${ }^{7}$ CARVAlhoSA, Modesto. Comentários à Lei de Sociedades Anônimas, $3^{\circ}$ volume: artigos 138 a 205 - 5 ed. rev. e atual. São Paulo: Saraiva, 2011. p. 415 e 416.

${ }^{8}$ Extrato da sessão de julgamento do Processo Administrativo Sancionador CVM 2007/1079. Voto do Diretor: Pedro Oliva Marcilio de Sousa. Diretor-Relator: Eli Loria. Presidente da sessão de julgamento: Marcelo Fernandez Trindade. j. 10.07.2007. Disponível em: [http://www.cvm.gov.br/sancionadores/sancionador/2007/20070710_RJ20071079.html]. Acesso em: 10.05.2016. 
É exatamente por isso que toda e qualquer regra estatutária ou que derive de aprovação assembleiar que de algum modo retire, restrinja ou limite o direito à informação do acionista será inválida, visto que põe em cheque a essencialidade do princípio.

Dessa forma se depreende que, sendo o princípio do full disclosure premissa de enorme significação para o mercado de valores mobiliários, como demonstrado, o direito à informação se revela como instrumento ideal, verdadeira conditio sine qua non, para viabilizar o pleno exercício pelos acionistas, dos demais direitos sociais e, de resto, para a proteção dos investidores em geral. ${ }^{9}$

${ }^{9}$ MILLER, op. cit. p. 126. 


\section{O Elemento subjetivo no Insider Trading Brasileiro}

\subsection{Necessidade de Auferir Vantagem?}

Estudando o parágrafo $4^{\circ}$ do art. $155^{10}$ da Lei das S/A, nota-se que grande parte da doutrina entende que é possível dividi-lo em três principais elementos para a caracterização do insider trading: (i) a necessidade de existência efetiva de informação relevante ainda não divulgada, (ii) a presunção do acesso à informações privilegiadas por insiders primários e secundários e (iii) a necessidade, ou não, de demonstração pela CVM que a negociação com informações relevantes ocorreu com a finalidade de auferir vantagem, para si ou para outrem. Nesse capítulo se abordará mais aprofundadamente o terceiro elemento.

No livro Mercado de Capitais - Regime Jurídico, como pode se depreender do trecho transcrito abaixo, os autores afirmam que para a configuração do insider trading é essencial que o agente tenha negociado em posse de informações privilegiadas com a finalidade precípua de obter vantagem para si ou para outrem.

"O tipo - uso de informação privilegiada - apresenta elemento subjetivo especial, tratando-se, portanto, de dolo específico: o insider deve não só ter consciência da ilicitude, como também desejar o resultado, a vantagem indevida." 11

\footnotetext{
${ }^{10} \mathrm{O}$ art. $155 \S 4^{\mathrm{o}}$ da Lei das S/A dispõe o seguinte: É vedada a utilização de informação relevante ainda não divulgada, por qualquer pessoa que a ela tenha tido acesso, com a finalidade de auferir vantagem, para si ou para outrem, no mercado de valores mobiliários. (Incluído pela Lei nº 10.303, de 2001)

${ }^{11}$ EIZIRIK, Nelson, GAAL, Ariádna B., PARENTE, Flávia e HENRIQUES, Marcus de Freitas, Mercado de Capitais - Regime Jurídico, 3.ed. revista e ampliada. - Rio de Janeiro: Renovar, 2011, p. 564.
} 


\section{A própria redação do parágrafo $4^{\circ}$ do art. 155 da Lei das S/A, é expressa no sentido de exigir a obtenção de vantagem para configuração do insider. No entanto, apesar disso, o art. 13 da Instrução CVM 358/2002 ${ }^{12}$ dispõe de maneira diversa deixando de mencionar a finalidade de auferir vantagem, ou seja, determina simplesmente a vedação à negociação quando se tratar de operação}

\footnotetext{
${ }^{12} \mathrm{O}$ art. 13 da Instrução CVM 358/02 dispõe da seguinte forma:

Art. 13. Antes da divulgação ao mercado de ato ou fato relevante ocorrido nos negócios da companhia, é vedada a negociação com valores mobiliários de sua emissão, ou a eles referenciados, pela própria companhia aberta, pelos acionistas controladores, diretos ou indiretos, diretores, membros do conselho de admi

nistração, do conselho fiscal e de quaisquer órgãos com funções técnicas ou consultivas, criados por disposição estatutária, ou por quem quer que, em virtude de seu cargo, função ou posição na companhia aberta, sua controladora, suas controladas ou coligadas, tenha conhecimento da informação relativa ao ato ou fato relevante.

§1ํㅡ A mesma vedação aplica-se a quem quer que tenha conhecimento de informação referente a ato ou fato relevante, sabendo que se trata de informação ainda não divulgada ao mercado, em especial àqueles que tenham relação comercial, profissional ou de confiança com a companhia, tais como auditores independentes, analistas de valores mobiliários, consultores e instituições integrantes do sistema de distribuição, aos quais compete verificar a respeito da divulgação da informação antes de negociar com valores mobiliários de emissão da companhia ou a eles referenciados.

§2 Sem prejuízo do disposto no parágrafo anterior, a vedação do caput se aplica também aos administradores que se afastem da administração da companhia antes da divulgação pública de negócio ou fato iniciado durante seu período de gestão, e se estenderá pelo prazo de seis meses após o seu afastamento.

§3ำ A vedação do caput também prevalecerá:

I - se existir a intenção de promover incorporação, cisão total ou parcial, fusão, transformação ou reorganização societária; e

II - em relação aos acionistas controladores, diretos ou indiretos, diretores e membros do conselho de administração, sempre que estiver em curso a aquisição ou a alienação de ações de emissão da companhia pela própria companhia, suas controladas, coligadas ou outra sociedade sob controle comum, ou se houver sido outorgada opção ou mandato para o mesmo fim.

$\S 4^{\circ}$ Também é vedada a negociação pelas pessoas mencionadas no caput no período de 15 (quinze) dias que anteceder a divulgação das informações trimestrais (ITR) e anuais (DFP) da companhia, ressalvado o disposto no $\S 2^{\circ}$ do art. 15-A.

$\S 5^{\circ}$ As vedações previstas no caput e nos $\S \S 1^{\circ}$, $2^{\circ}$, e $3^{\circ}$, inciso I, deixarão de vigorar tão logo a companhia divulgue o fato relevante ao mercado, salvo se a negociação com as ações puder interferir nas condições dos referidos negócios, em prejuízo dos acionistas da companhia ou dela própria.

$\S 6^{\circ} \mathrm{A}$ vedação prevista no caput não se aplica à aquisição de ações que se encontrem em tesouraria, através de negociação privada, decorrente do exercício de opção de compra de acordo com plano de outorga de opção de compra de ações aprovado em assembleia geral, ou quando se tratar de outorga de ações a administradores, empregados ou prestadores de serviços como parte de remuneração previamente aprovada em assembleia geral.

$\S 7^{\circ}$ As vedações previstas no caput e nos $\S \S 1^{\circ}$ a $3^{\circ}$ não se aplicam às negociações realizadas pela própria companhia aberta, pelos acionistas controladores, diretos ou indiretos, diretores, membros do conselho de administração, do conselho fiscal e de quaisquer órgãos com funções técnicas ou consultivas, criados por disposição estatutária, de acordo com os procedimentos previstos no art. 15-A.
} 
ocorrida antes da divulgação do fato relevante, desde que aquele que detém a informação tenha ciência de que se trata e informação ainda não divulgada ao mercado.

Dessa forma, entende-se que a CVM optou por definir períodos de vedação de negociação no mercado para determinadas pessoas justamente pela dificuldade em se demonstrar a intenção do agente nesses casos.

Presume-se, assim, que todas as transações envolvendo essas pessoas, nos períodos determinados pela Instrução, teriam sido realizadas com base em informações privilegiadas e com dolo específico para obter vantagem para si ou para outrem.

“A opção da regulamentação da CVM de estabelecer certos períodos de vedação de negociação parece claramente ter decorrido da dificuldade da prova da intenção de obter vantagem com uma negociação. Daí o caminho das normas regulamentares vedando a negociação, na presunção de que existindo, naqueles períodos, informação relevante não divulgada, a negociação teria sido presumidamente feita com a utilização da informação e com a finalidade de auferir vantagem." $" 13$

Apesar disso, a regulamentação da CVM não afastou o elemento subjetivo da prática de insider, e nem poderia, visto que não tem competência para alterar o disposto em Lei. A norma da CVM apenas inverte o ônus da prova, isto é, atribui ao investigado o ônus de demonstrar que não negociou utilizando informações privilegiadas objetivando auferir vantagem.

“(...) parece admissível essa forma de proceder da CVM mesmo na ausência de norma legal criando a presunção. $O$ poder do órgão regulamentar deve abranger o de facilitar a aplicação da norma regulamentada mediante a criação de presunções

\footnotetext{
${ }^{13}$ TRINDADE, Marcelo Fernandez, Mútuo de ações e insider trading. In: CASTRO, Rodrigo Rocha Monteiro de; WARDE JÚNIOR, Walfrido Jorge; GUERREIRO, Ana Carolina Dias Tavares (coord.). Direito Empresarial e outros estudos em homenagem ao Professor Tavares Guerreiro, São Paulo: Quartier Latin, 2013, p. 527.
} 
quanto à sua incidência. Mas isso só é verdade porque se trata de presunção relativa (iuris tantum), que admite prova em contrário. Caso assim não fosse, a norma teria extrapolado o mandato legal, e seria ela própria ilegal." 14

Também é importante notar que as exceções admitidas pelos regulamentos da CVM trazem hipóteses de prova de que não foi feito uso de informação privilegiada em beneficio próprio ou de terceiros.

Seguindo o mesmo raciocínio, somente no caso do ilícito praticado pelos insiders primários seria possível a criação de uma presunção iuris tantum quanto a culpa presente da negociação do agente, sem que se torne necessário prová-la.

"Tratando-se, porém, de insider de mercado, ou seja, de pessoa que se encontra 'de fora' da companhia, cabe provar, para responsabilizá-lo, que ele tivera acesso à informação relevante e a utilizara com o objetivo precípuo de dela tirar vantagem indevida na compra e venda de valores mobiliários." 15

Apesar disso, há na doutrina quem discorde desses entendimentos argumentando que a comprovação de dolo ou culpa por parte do agente não seria necessária para se configurar a prática do insider trading, nem no insider primário nem no secundário:

"A convicção do juiz sobre a prática de insider trading deve ser haurida de dois elementos: $1 .^{\circ}$ ) a existência de fato relevante ainda não divulgado ao público (art. 157); $\left.2 .^{\circ}\right)$ a compra e venda, pelos insiders, de valores mobiliários emitidos pela companhia no período que medeia entre a posse da informação sigilosa e a sua divulgação junto ao público.

Estabelecidos esses dois fatos, estarão configurados os elementos objetivos de convencimento para a condenação dos insiders, seja por responsabilidade civil junto aos investidores prejudicados, seja para sua responsabilização junto à companhia (arts. 158 e 159), seja para aplicação das sanções administrativas decretadas pela Comissão de Valores Mobiliários." 16

\footnotetext{
${ }^{14}$ Idem.

${ }^{15}$ LEÃES, Luiz Gastão Paes de Barros. "A adoção do Chinese Wall e a repressão ao insider trading." Revista de Direto Bancário e do Mercado de Capitais. vol. 47. São Paulo: Ed. RT, 2010. p. 227.
}

${ }^{16}$ CARVALHOSA, op. cit. p. 315. 
No entanto, apesar de tal entendimento destoante, a CVM tem decidido em seus julgamentos pela necessidade de se comprovar a vontade do agente em obter vantagem indevida com a negociação, mesmo que por meio de prova indiciária, conforme se depreende da análise da decisão do Colegiado da CVM abaixo.

\begin{abstract}
"Ainda de acordo com a defesa, o Credit Suisse USA teria negociado units da Terna, durante o período vedado, para 'dar liquidez a um cliente, o qual necessitava de uma pequena quantidade de units para completar sua transação'.

Em continuidade, afirma a defesa que: 'essa negociação ter ocorrido na véspera da divulgação do fato relevante não passa de mera coincidência, e como tal deve ser aceita, sem consequências para o Defendente', que não deve ser responsabilizado, '(...) seja porque o momento da negociação foi definido por uma necessidade de um cliente; (...) seja porque a negociação não se coaduna com o comportamento de um insider que detivesse informação privilegiada'.

Conforme a defesa, portanto, o Credit Suisse USA não tinha a intenção de negociar as units da Terna e, tampouco, de obter vantagem com essa negociação. $O$ fez apenas para atender as necessidades de um cliente.

Nesse sentido, ainda que inicialmente tenham sido trazidos só argumentos, desacompanhados de qualquer prova, foi posteriormente protocolizado pela defesa um expediente confidencial que confirma, com suficientes elementos objetivos, a verossimilhança das alegações trazidas acerca das operações realizadas para atender às demandas do supracitado cliente.

A análise do expediente acima, em conjunto com alguns contra-indícios fáticos, opera a favor do acusado. De fato, ao analisar os negócios realizados, chama a atenção, de pronto, o baixo volume operado - notadamente se considerarmos o porte e a natureza da atividade desempenhada pelo acusado. Nota-se, ainda, que a compra e venda das units da Terna foram realizadas no mesmo dia (day trade), tendo, ao final, acarretado prejuízos para o acusado. E, principalmente, observo que tudo ocorreu antes da divulgação do fato relevante.

Entendo, assim, que os elementos probatórios acima são suficientes para, no caso concreto, desconstituir a base da acusação formulada e concluir que não restou provada efetiva violação do disposto no art. 13 e parágrafos da Instrução CVM 358/2002 pelo acusado, razão pela qual voto pela sua absolvição." ${ }^{17}$
\end{abstract}

\footnotetext{
${ }^{17}$ Extrato da sessão de julgamento do Processo Administrativo Sancionador CVM RJ 2010/4206. Diretor-Relator: Alexsandro Broedel Lopes. Presidente da sessão de julgamento: Maria Helena dos Santos Fernandes de Santana. j. 23.08.2011. Disponível em: [http://www.cvm.gov.br/sancionadores/sancionador/2011/20110823_RJ20104206.html]. Acesso em: 04.05.2016.
} 
Diante desse julgamento, não há dúvidas quanto ao entendimento que prevalece nos dias de hoje. A comprovação, mesmo que por meio de prova indiciária, da intenção do agente em auferir vantagem indevida com a negociação em posse de informação privilegiada é essencial para configuração da prática do insider.

No tocante ao resultado, diferente do que foi visto anteriormente, a doutrina e jurisprudência têm entendido que para configuração do insider não é uma exigência legal a comprovação efetiva da obtenção da vantagem ilícita pelo agente.

A própria CVM já concluiu dessa forma ao decidir o Processo Administrativo Sancionador $\mathrm{n}^{\circ}$ 04/2004, ocasião em que seu então presidente Marcelo Trindade afirmou:

\begin{abstract}
"A produção do resultado, em si mesma - isto é, no caso concreto, a efetiva obtenção da vantagem visada - é elemento objetivo, não se confunde com a finalidade (que é a intenção do agente), e não integra a conduta descrita no art. $155, \S \S 1^{\circ}$ e $4^{\circ}$, da Lei das S/A, e no art. 13 da Instrução 358/2002.

Assim, parece-me que, no caso concreto, não há que perquirir se houve ou não vantagem, mas sim se o comportamento dos indiciados revela que a aquisição se deu sem a finalidade de obter lucro com a utilização da informação. Além disto, como visto, há que verificar se havia, ou não, fato relevante pendente de divulgação quando da aquisição de ações pelos indiciados." ${ }^{\prime 18}$
\end{abstract}

No mesmo sentido foi o voto da então Diretora Luciana Dias no Processo Administrativo Sancionador CVM RJ 2011/3665, julgado em 2012:

"Mesmo que os acusados não tivessem apurado lucro nas respectivas operações, como efetivamente ocorreu, já é consolidado o entendimento do Colegiado da CVM de que o lucro não é requisito necessário para a caracterização do ilícito de uso indevido de informações privilegiadas. A efetiva consecução da vantagem não integra a

\footnotetext{
${ }^{18}$ Extrato da sessão de julgamento do Processo Administrativo Sancionador CVM 04/2004. DiretorRelator e Presidente da sessão de julgamento: Marcelo Fernandez Trindade. j. 28.06.2006. Disponível em: [http://www.cvm.gov.br/sancionadores/sancionador/2006/20060628_0404.html]. Acesso em: 05.05.2016.
} 
caracterização do insider, basta, simplesmente, a negociação por qualquer pessoa que detenha informação privilegiada. Afasto, portanto, também essa linha de defesa." 19

Nesse sentido, pode-se compreender que, apesar de algumas vozes destoantes, a doutrina e a jurisprudência têm concordado com o entendimento de que a comprovação, mesmo que por meio de prova indiciária, da intenção do agente em obter vantagem para si ou para outrem é requisito essencial para a configuração da prática do insider trading.

\subsection{Diferenças entre a Lei das Sociedades Anônimas e a Instrução da CVM}

Como visto no capítulo anterior, o caráter repressivo a prática do insider trading está claramente disposto no parágrafo $4^{\circ}$ do art. 155 , introduzido na reforma da Lei das S/A pela Lei 10.303/2001, ao vedar a utilização de informação relevante ainda não divulgada por qualquer pessoa que a ela tenha acesso, com a finalidade de auferir vantagem, para si ou para outrem, no mercado de valores mobiliários.

Apesar de tal artigo estar disposto no contexto do dever de lealdade dos administradores, a vedação à pratica do insider não se restringe apenas a estes. Esse vem sendo o entendimento pacífico da doutrina e o aplicado pela CVM em seus julgamentos.

\footnotetext{
${ }^{19}$ Extrato da sessão de julgamento do Processo Administrativo Sancionador CVM RJ 2011/3665. Diretora-Relatora: Luciana Dias. Presidente da sessão de julgamento: Maria Helena dos Santos Fernandes de Santana. j. 03.04.2012. Disponível em: [http://www.cvm.gov.br/sancionadores/sancionador/2012/20120403_RJ20113665.html]. Acesso em: 05.05.2016.
} 
A título de exemplificação, pode-se citar o Processo Administrativo Sancionador $11 / 2008^{20}$, no qual os indiciados Jorge Rzezinski e Marcelo Rzezinski arguiram preliminar de erro de tipificação, indicando que a vedação do $\S 4^{\circ}$ do art. 155 da Lei das S/A deveria ser interpretada restritivamente de acordo com o caput e inciso III do mesmo dispositivo, de forma a referir-se apenas ao administrador ou pessoa com vínculo profissional com a companhia.

O mesmo argumento foi utilizado pelas defesas dos indiciados Luciano Decourt e Maria Elisabeth Decourt no curso do PAS RJ 2011/3665. ${ }^{21}$ Nos dois casos a CVM decidiu que após a Lei 10.303/01 que inseriu o parágrafo $4^{\circ}$ ao art. 155, a vedação da conduta de insider passou a ser destinada a qualquer pessoa que tenha acesso a informação relevante e não apenas aos administradores da companhia.

Neste cenário, a doutrina discorre sobre a introdução do $\S 4^{\circ}$ do art. 155 na Lei das S/A pela Lei 10.303/2001:

“(...) pressupõe que o administrador representa o tipper, que transmite ao tippee a informação não divulgada. Há sempre uma correlação entre o administrador e o terceiro. (...) Assim, por força do novo $\S 4^{\circ}$ do art. 155, o insider será também a pessoa que, em conluio ou mesmo por negligência do administrador, efetivamente se aproveita das informações privilegiadas para obter ganhos ou evitar prejuízos, mediantes a compra e/ou a venda precipitada de valores mobiliários de emissão da companhia, os quais, necessariamente, seriam negociados em outras bases ou simplesmente não o

\footnotetext{
${ }^{20}$ Extrato da sessão de julgamento do Processo Administrativo Sancionador CVM 11/2008. DiretoraRelatora: Luciana Dias. Presidente da sessão de julgamento: Otavio Yazbek. j. 21.08.2012. Disponível em: [http:/www.cvm.gov.br/sancionadores/sancionador/2012/20120821_1108.html]. Acesso em: 24.05.2016.

${ }^{21}$ Extrato da sessão de julgamento do Processo Administrativo Sancionador CVM RJ 2011/3665. Diretora-Relatora: Luciana Dias. Presidente da sessão de julgamento: Maria Helena dos Santos Fernandes de Santana. j. 03.04.2012. Disponível em: [http://www.cvm.gov.br/export/sites/cvm/sancionadores/sancionador/anexos/2012/20120403_PAS_RJ 20113665.pdf]. Acesso em: 24.05.2016.
} 
seriam se o público tivesse simultaneamente conhecimento dessas mesmas informações." 22

Diante disso, entende-se que os insiders podem ser divididos em dois grandes grupos. No primeiro os insiders primários ou tippers, aqueles que têm acesso direto à informação relevante por serem membros da administração e possuírem conhecimento suficiente para saber quais as informações relevantes e por que. Já o segundo grupo os insiders secundários também conhecidos como tippees, aqueles que recebem a informação de alguém que possui acesso direto.

\begin{abstract}
"São considerados insiders primários, ou tippers, pois dão a dica (tip, em inglês) da informação privilegiada, aqueles que possuem vínculo direto com a companhia emissora dos papéis negociados com o uso de informações privilegiadas, como acionistas, administradores e funcionários, bem como profissionais e instituições sem vínculo direto com a companhia emissora e que prestam serviços relacionados às operações ou negócios que geram a informação privilegiada. Consideram-se como insiders secundários, ou tippees, pois recebem as informações de algum insider primário, os agentes de mercado, incluindo bancos e pessoas ligadas aos bancos, corretoras de valores e seus funcionários, ex-administradores, fundos e pessoas ligadas a sua administração, investidores, parentes de indiciados do mercado e parentes de internos da companhia." 23
\end{abstract}

Como se pode depreender do trecho acima, ambos podem incorrer no uso indevido de informação privilegiada, tendo em vista que qualquer um que possua uma informação privilegiada torna-se um potencial sujeito ativo desse ilícito.

Desse modo, a principal diferença entre eles está no fato de que os tippees não podem ser apenados pelo art. 27-D da Lei $6.385 / 76^{24}$, o qual prevê a prática

\footnotetext{
${ }^{22}$ CARVAlHOSA, Modesto; EIZIRIK, Nelson. A nova Lei das S/A., São Paulo: Saraiva, 2002. pp. $322-$ 323.

${ }^{23}$ PRADO, Viviane Muller; VILELA, R. Radiografia de insider trading na CVM. 2014. (Relatório de pesquisa).
}

${ }^{24}$ O Art. 27-D da Lei 6.385/76 dispõe da seguinte forma: Utilizar informação relevante ainda não divulgada ao mercado, de que tenha conhecimento e da qual deva manter sigilo, capaz de propiciar, para si ou para outrem, vantagem indevida, mediante negociação, em nome próprio ou de terceiro, com valores mobiliários: 
do insider como um ilícito penal, isto é, podem ser responsabilizados civil e administrativamente, mas não penalmente, visto não serem os sujeitos ativos previstos pelo dispositivo supracitado, ao contrário dos insiders primários, que além de sofrer pena de reclusão de 1 a 5 anos, e multa de até três vezes o montante da vantagem ilícita obtida em decorrência do crime, sofrem ainda uma presunção de cometimento do crime de insider, cabendo a eles o ônus de provar que não houve nexo de causalidade entre o dano causado por eles e o resultado (assimetria de informações e falta de transparência ao mercado) como visto nos capítulos anteriores. ${ }^{25}$

O ex-Diretor da CVM, Eli Loria, em seu voto no julgamento do caso de insider trading ocorrido por ocasião da oferta hostil lançada pela Sadia para a aquisição das ações da Perdigão, afirmou:

\footnotetext{
"Ademais, qualquer pessoa que realize uma operação com a utilização de informação privilegiada pode ser responsabilizada por esta infração administrativa.
}

A vantagem indevida que o "insider" possui frente a sua contraparte fere os princípios da igualdade no acesso à informação e da negociação por todos nas mesmas bases, afetando a confiança na transparência e eficiência do mercado e desestimulando a participação dos investidores no mercado de valores mobiliários. Tal conceito encontra-se insculpido na Nota Explicativa ${ }^{\circ} 28$ à Instrução $\mathrm{CVM} \mathrm{n}^{\circ} 31$, de 8 de fevereiro de 1984, cabendo reproduzir um trecho que traduz o pensamento do órgão regulador:

"O objetivo primordial do sistema de divulgação acima articulado é propiciar ao investidor uma decisão consciente, embasada numa ampla gama de informações que espelhem fidedignamente a situação da companhia. Garantida a efetividade do sistema de informações, pretende-se, adicionalmente, garantir ao investidor que pessoas intimamente ligadas aos negócios da companhia não poderão utilizar-se de

\footnotetext{
Pena - reclusão, de 1 (um) a 5 (cinco) anos, e multa de até 3 (três) vezes o montante da vantagem ilícita obtida em decorrência do crime.

Exercício Irregular de Cargo, Profissão, Atividade ou Função.

${ }^{25}$ BLOK, Marcella. "Insider Trading: o descumprimento do dever de lealdade pelo uso de informações privilegiadas". Revista de Direito Bancário e do Mercado de Capitais, ano 15, n. 55, São Paulo: Revista dos Tribunais, jan/mar. 2012. pp. 83-129.
} 
informações ainda não disseminadas ao público. Só assim se promoverá a confiabilidade do investidor no mercado de valores mobiliários".,"26

No mesmo sentido o ex- Diretor, ainda em seu voto, cita a doutrina estrangeira de DANIEL RUIZ:

\begin{abstract}
"Em primer lugar, dado el ambito subjetivo de aplicación de la infracción, puede ser autor cualquiera persona que la use independientemente de como la haya obtenido (...). Desde el momento que una persona lleve a cabo una operación empleando información privilegiada de forma dolosa, o culposa si há acedido a ella por su puesto profesional, es responsable de la infracción administrativa de uso ilegal de información privilegiada." 27 e 28
\end{abstract}

Para o legislador brasileiro são considerados insiders as pessoas que em razão de sua posição têm acesso a informações capazes de influir de modo ponderável na cotação dos valores mobiliários de emissão da companhia, são elas: (i) administradores, conselheiros e diretores da companhia (art. 145 da Lei das S/A), (ii) membros de quaisquer órgãos, criados pelo estatuto da companhia, com funções técnicas ou destinadas a aconselhar os administradores (art. 160 da Lei das S/A), (iii) membros do conselho fiscal (art. 165 da Lei das S/A), (iv) subordinados das pessoas acima referidas (art. $155 \S 2^{\circ}$ da Lei das S/A), (v) terceiros de confiança dessas pessoas (art. $155 \$ 2^{\circ}$ da Lei das S/A) e (vi) acionistas controladores (art. 22, V, da Lei 6.385/76).

\footnotetext{
${ }^{26}$ Extrato da sessão de julgamento do Processo Administrativo Sancionador CVM SP2007/0117. DiretorRelator: Eli Loria. Presidente da sessão de julgamento: Maria Helena dos Santos Fernandes de Santana. j. 26.02.2008. Disponível em: [http://www.cvm.gov.br/sancionadores/sancionador/2008/20080226_SP20070117.html]. Acesso em: 09.05.2016.
}

${ }^{27}$ RUIZ, Daniel Entrena. El empleo de información privilegiada en el mercado de valores: un estudio de su régimen administrativo sancionador. España: Editorial Aranzadi, 2006, p. 273.

${ }^{28}$ Tradução livre: Em primeiro lugar, dado o âmbito subjetivo de aplicação da infração, o autor pode ser qualquer pessoa que a (informação) use independentemente de como a tenha obtido.

(...)

Desde o momento que uma pessoa leve a cabo uma operação se utilizando de uma informação privilegiada com dolo ou culpa, se ela tiver tido acesso por questões profissionais, deve ser responsabilizado pela infração administrativa de uso ilegal de informação privilegiada (insider trading). 
Embora a lei não tenha definido explicitamente o termo insider, em seus arts. 155 a 157 combinados com os arts. 145, 160 e 165, ao tratar dos deveres de lealdade e de prestar informações, por parte dos administradores e pessoas a eles equiparados, emite implicitamente o conceito. Também a Lei 6.385/76 estabelece que a CVM expedirá normas, aplicáveis à companhia aberta, sobre informações que devem ser prestadas por administradores e acionistas controladores.

Diante disso, o art. 155 da Lei das S/A traz uma lista de condutas proibidas, rol que não deve ser entendido como taxativo, isto é, a autoridade judiciária pode estabelecer outras formas de violação ao dever de lealdade.

Seguindo este mesmo raciocínio, o professor e advogado FRANCISCO MÜSSNICH dispõe em seu artigo A utilização desleal de informações privilegiadas - "Insider Trading" - no Brasil e nos Estados Unidos que:

"O alcance dos arts. 155 e 157 da Lei 6.404/76 é aparentemente muito limitado, pois apenas os administradores de companhias abertas estão sujeitos às proibições legais.

(...)

Esta interpretação estreita das pessoas que são objeto de responsabilidade pela utilização desleal de informações privilegiadas, está em completo desacordo com a filosofia embutida na Lei 6.404/76 na sua tentativa de legal e culturalmente modificar o comportamento empresarial no Brasil.

Da leitura do art. 155, depreende-se que o mesmo foi criado, entre outras coisas, para proibir os administradores de utilizarem informações que ainda não tenham sido divulgadas, para seu próprio benefício, mas não apenas para este fim. Implícita no artigo existe também a proibição do uso indevido de informações por terceiros de confiança do administrador, que em consequência desta relação especial (fiduciária) são equiparados pela própria Lei 6.404/76 aos administradores.

Da leitura do art. 157, depreende-se também, entre outras coisas, que o mesmo obrigou aos administradores divulgarem imediatamente toda e qualquer informação relevante sobre a empresa e criou para os acionistas que a solicitarem o dever de não utilizá-las em fins outros que não os do legítimo interesse da empresa." ${ }^{29}$

\footnotetext{
${ }^{29}$ MÜSSNICH, Francisco Antunes Maciel. "A utilização desleal de informações privilegiadas - "Insider Trading" - no Brasil e nos Estados Unidos." Revista de Direito Mercantil, Industrial, Econômico e Financeiro. vol.34. São Paulo: Ed. RT, 1979, p. 35.
} 
Desse modo, ambos os artigos citados acima, devem ser interpretados em conjunto com o parágrafo $5^{\circ}$ do art. 158, isto porque este é o dispositivo legal que impõe às pessoas que concorram para a prática do ato ilícito os mesmos deveres impostos aos administradores.

Consequentemente, os terceiros vinculados por qualquer razão aos administradores terão em função de sua relação especial (fiduciária), as mesmas obrigações impostas a eles e serão responsabilizados pela utilização desleal de informações privilegiadas ainda não divulgadas.

Dando continuidade ao presente estudo, partimos para análise das normas expedidas pela CVM. Tratando sobre o dever de sigilo, cabe destacar o artigo $8^{\circ}$ da Instrução 358/2002:

"Dever de guardar sigilo

Art. $8^{\circ}$ Cumpre aos acionistas controladores, diretores, membros do conselho de administração, do conselho fiscal e de quaisquer órgãos com funções técnicas ou consultivas, criados por disposição estatutária, e empregados da companhia, guardar sigilo das informações relativas a ato ou fato relevante às quais tenham acesso privilegiado em razão do cargo ou posição que ocupam, até sua divulgação ao mercado, bem como zelar para que subordinados e terceiros de sua confiança também o façam, respondendo solidariamente com estes na hipótese de descumprimento."

Antes da informação que pode influir no comportamento dos investidores ser divulgada ao mercado ela deve ser guardada em absoluto sigilo. Como visto anteriormente, os administradores não podem utilizar a informação ainda não divulgada para obter qualquer tipo de vantagem para si ou para outrem.

No entanto, no exato momento que segue à publicação da informação pelos administradores ao mercado a mesma deixa de ser sigilosa. Assim, se por qualquer razão a informação venha perder seu caráter confidencial, não mais se presta ao insider trading, isto porque, a informação já disseminada ainda que de 
forma irregular e mesmo que seja extremamente relevante, será uma informação de mercado a qual se presume estar refletida nas expectativas dos agentes que negociam valores mobiliários. ${ }^{30}$

Afinal, o dever de lealdade se relaciona aos atos em que estão presentes: (i) conflito de interesse entre o administrador e a Companhia e entre companhias por terem administradores em comum; (ii) vantagem obtida indevidamente por administrador em oportunidades que pertenciam à companhia; (iii) administrador competindo com a companhia; (iv) informações falsas ou indevidas aos acionistas; (v) negociação do insider; (vi) abuso da minoria e (vii) venda de controle. ${ }^{31}$

Consequentemente, será desleal o administrador que não guardar reserva dos negócios sociais, permitindo o vazamento de informações sigilosas e reservadas da companhia a pessoas, que possam utilizá-las em aproveito próprio, fraudando interesses de acionistas e investidores.

Por fim, é importante ressaltar que, mesmo que os responsáveis pela violação ao dever de lealdade sejam os subordinados, ou os terceiros de confiança do administrador, tal fato não afasta sua responsabilidade, a não ser que não tenha tido conhecimento da violação.

\footnotetext{
${ }^{30}$ BARBOSA, Marcelo; BARROS, Octavio Fragata; BRICK, Bruna Zoghbi; CAMPINHO, Bernardo Capela. Direito societário e mercado de capitais. Rio de Janeiro: Editora FGV, 2009. Vol. 2, t. 2, p. 78.

${ }^{31}$ CORREA LIMA, Osmar Brina. Responsabilidade civil dos administradores de sociedades anônimas. Rio de Janeiro: Aide, 1989, p. 75.
} 


\title{
2.3. Inversão do Ônus da Prova, solução pacífica
}

Como iremos ver mais profundamente nos próximos capítulos, é de entendimento pacífico na doutrina e na jurisprudência que existe entre os agentes uma distinção relevante entre os insiders primários e os secundários.

"São primários os insiders que detêm acesso às informações privilegiadas na sua fonte, seja por sua posição funcional, como ocorre com os administradores, seja por sua condição de acionistas controladores. Já os insiders secundários são aqueles que recebem a informação privilegiada dos primários e não estão obrigados ao dever de sigilo, não se lhes aplicando, assim, a norma penal, embora possam ser punidos administrativamente." ${ }^{32}$

Seguindo esse entendimento, os insiders primários por serem administradores possuem uma presunção iuris tantum de que tiveram acesso a informação privilegiada antes de negociar, dado a posição que ocupam. Essa presunção relativa deve ser analisada no caso a caso, visto que os estatutos das companhias podem dispor de forma a especializar as funções dos diretores o que dificultaria o acesso à informação.

\begin{abstract}
“Assim, um diretor jurídico, por exemplo, pode não ter tido acesso a determinada informação financeira, de conhecimento exclusivo do diretor da área. Da mesma forma, os membros do conselho de administração o mais das vezes somente têm acesso a determinadas informações quando elas lhes são encaminhadas pelos diretores." ${ }^{33}$

Também é muito importante analisar o comportamento prévio do administrador e o momento da negociação, isto é verificar se lhe era usual a compra e venda de ações da companhia ou se somente passou a fazê-lo diante da divulgação de um fato relevante. Isso se torna relevante especialmente
\end{abstract}

\footnotetext{
${ }^{32}$ EIZIRIK, Nelson. A Lei das S/A Comentada. Volume III - $2^{\text {a }}$ ed. rev. e ampliada - artigos 138 a 205. São Paulo: Quartier Latin, 2015. p.376.

${ }^{33}$ Ibid. p.377.
} 
porque, em todas as esferas a prova direta do ilícito é praticamente impossível, fazendo-se necessário recorrer aos indícios.

Nesse mesmo sentido foi o entendimento da ex-Diretora Norma Parente em seu voto no Processo Administrativo Sancionador RJ 24/00:

"A prova indiciária autoriza a condenação desde que haja indícios graves, precisos e concordes.

(..)

A prova indiciária é uma prova indireta, circunstancial, de inferências, partindo de dados e circunstâncias conhecidos (fatos provados) para os fatos desconhecidos (fatos probandos), através de um raciocínio de estrita lógica formal. Não é uma prova menor, nem imperfeita, e constitui prova suficiente a autorizar a condenação. É inquestionavelmente válida, porque fundada na razão, e tem um significativo peso na elucidação dos fatos. Distingue se da presunção, que não é meio de prova, mas mero exercício de abstração lógico-dedutiva, prescindindo de qualquer elemento específico sem amparo concreto e probatório. Já o indício subordina-se à prova, não subsistindo sem uma premissa, que é a circunstância indiciante provada.

Conforme entendimento reiterado desta CVM, não é qualquer indício que enseja a condenação, mas a prova indiciária, quando representada por indícios graves, precisos e concordes que levem a uma conclusão robusta e fundamentada acerca do fato que se quer provar." ${ }^{34}$

Os administradores devem ainda cuidar para que seus subordinados também não utilizem a informação confidencial em proveito próprio. Isto é, além de não usarem eles próprios a informação sigilosa é também de responsabilidade dos administradores da companhia impedir que tal informação seja indevidamente utilizada por terceiros de sua confiança.

Exatamente por essa razão que a companhia deve estabelecer políticas internas de controle de fluxo de informações e compliance interno, visto que havendo culpa ou dolo do administrador no vazamento da informação relevante,

\footnotetext{
${ }^{34}$ Extrato da sessão de julgamento do Processo Administrativo Sancionador CVM RJ 24/00. DiretorRelator: Wladimir Castelo Branco Castro. Presidente da sessão de julgamento: Marcelo Fernandez Trindade. j. 18.08.2005. Disponível em: [http://www.cvm.gov.br/sancionadores/sancionador/2005/20050818_2400.html]. Acesso em: 15.05.2016.
} 
ele responderá solidariamente com os subordinados ou terceiros de confiança pelos danos causados a terceiros.

Além de todos esses aspectos, é também de suma importância atentar para o fato de que o insider prejudica não só as partes envolvidas na negociação, mas também o próprio mercado como um todo.

"É importante insistir: o ilícito do insider trading fere não apenas as pessoas envolvidas na operação econômica concretamente considerada, mas, a rigor e, sobretudo, a própria coletividade no âmbito do mercado de valores mobiliários e, como se viu, o próprio mercado. Ou, dito de maneira mais concisa, a prática afeta diretamente os chamados interesses difusos, isto é, aqueles interesses indivisíveis, que transcendem o individual e cujos titulares são pessoas indeterminadas, mas unidas por circunstâncias de fato os investidores de modo geral. ${ }^{35}$

Nesse sentido, também caminha KARINA TEREZA DA SILVA MACIEL, em seu artigo Efetividade da Repressão ao Insider Trading, escrito para Revista de Direito Empresarial, onde expressa seu entendimento:

“(...) para além do alcance e da extensão de danos que a conduta poderia causar, há que se lembrar de que o abuso de informação ocorre num mercado anônimo e massificado, fato que, se não impede, dificulta em muito a individualização dos lesados. ${ }^{36}$

Como visto anteriormente, discute-se a existência de uma divergência entre a Instrução da CVM e a Lei das S/A. Apesar de não estar previsto expressamente no parágrafo $1^{\circ}$ do art. 13 da Instrução 358/02 o elemento subjetivo isto não quer dizer que a vedação nele presente seja absoluta. Muito pelo contrário, tal fato apenas comprova a presunção do artigo da Instrução no

\footnotetext{
${ }^{35}$ MÜSSNICH, Francisco Antunes Maciel. O Insider Trading no Direito Brasileiro. 2015. 148 f. Dissertação (Mestrado em Direito da Regulação) - Fundação Getúlio Vargas - FVG. Rio de Janeiro, 2015. p. 19.

${ }^{36}$ MACIEL, Karina Teresa da Silva, MARTIN, Antônio. Efetividade da repressão ao insider trading. Revista de Direito Empresarial, São Paulo, v. 3. maio 2014. p. 149.
} 
sentido de que quem realiza as operações, o faz baseado nessas informações privilegiadas.

Dessa forma, o que a Instrução fez foi criar uma presunção relativa com base apenas nos indícios no sentido de que o insider agiu com a intenção de auferir vantagem.

É importante ressaltar o caráter relativo dessa presunção, isto é, a presunção trazida pela regulamentação normativa admite provas em contrário, visto que, se assim não fosse se constituiria uma responsabilidade equivalente à responsabilidade objetiva, o que não é admitido em se tratando de um processo sancionador.

\begin{abstract}
"Essa presunção, como se passará a expor, é relativa, admitindo prova em contrário. Interpretação diversa seria inteiramente incompatível com o atual ordenamento jurídico brasileiro.

Diz- se que a presunção contida no $\S 1^{\circ}$ do artigo 13 , como todas em sede de direito administrativo sancionador, pode ser desconstruída por prova em contrário porque, afinal, em matéria de direito punitivo, não é possível aceitar uma presunção que não possa ser elidida. A não aceitação de prova em contrário constituiria uma responsabilidade equivalente à responsabilidade objetiva, o que não é admitido em se tratando de um processo sancionador." ${ }^{37}$
\end{abstract}

Corroborando esse entendimento, DEMIAN GUEDES dispõe que:

"Sob a ótica um pouco diferente, alguns publicistas brasileiros, preocupados especificamente com os atos administrativos sancionadores (inclusive de natureza disciplinar), focalizam o estudo da verdade material e do ônus da prova no processo administrativo, à luz do princípio da presunção da inocência. Referido princípio, de origem processual penal, possui aplicação também no campo administrativo (especialmente nos processos sancionadores e disciplinares, nos quais a figura do ‘acusado' é mais evidente). ${ }^{\text {3 }} 8$

\footnotetext{
${ }^{37}$ Ibid. p. 36 e 37.

${ }^{38}$ GUEDES, Demian. Processo administrativo e democracia: uma reavaliação da presunção de veracidade. Belo Horizonte: Fórum, 2007. p. 125.
} 
Por todo exposto no capítulo, resta claro que, atualmente, a doutrina e a jurisprudência são pacíficas no sentido de que a norma do art. 13 da Instrução CVM 358/02 não possuí o caráter de alterar a regra expedida pela Lei das S/A, e nem poderia. O que ela faz é inverter o ônus da prova, atribuindo ao investigado o ônus de demonstrar que não negociou utilizando informações privilegiadas objetivando auferir vantagem. 


\section{A Punibilidade do Insider Trading no Direito Brasileiro}

\subsection{Diferenças entre prova indiciária e indício no Insider Trading}

Diante de todos os argumentos estudados até agora, percebe-se que a vedação da prática do insider possui fundamentos éticos e econômicos. Isto porque, se do ponto de vista ético o ilícito se configura um ato de deslealdade a negociação com informações que as outras pessoas do mercado não têm acesso $^{39}$, do ponto de vista econômico, prejudica a autoregulação do mercado, fazendo com que os preços negociados não correspondam a realidade e principalmente, abalando a confiança necessária no âmbito das relações negociais. ${ }^{40}$ Passamos agora a discutir as provas necessárias para sua punibilidade.

A definição legal de indício, como prova indiciária, contida no art. 239 do Código de Processo Penal, deixa muito clara a necessidade de haver uma circunstância conhecida e provada que autorize, por dedução, a existência de outras circunstâncias:

"Art. 239. Considera-se indício a circunstância conhecida e provada, que, tendo relação com outro fato, autorize, por indução, concluir-se a existência de outra ou outras circunstâncias."

Portanto, a mera plausibilidade teórica de que determinada situação ocorra ou tenha ocorrido não autoriza nem a formulação de uma acusação, muito menos condenação.

\footnotetext{
${ }^{39}$ CAMPOS, Luiz Antonio de Sampaio. Deveres e responsabilidades. In: LAMY Filho, Alfredo; Pedreira, José Luiz Bulhoes (coord.). Direito das Companhias. Rio de Janeiro: Forense, 2009. v. 1. p. 1.151 .
}

${ }^{40}$ MÜSSNICH, 2015. op. cit. p. 24. 
Daí porque já advertiu FABIO KONDER COMPARATO que:

"Por aí se vê que a presunção indiciária não é, propriamente, uma prova, mas um juízo dedutivo a partir de fatos provados. Se se tratasse de prova, ela poderia servir, em matéria penal, à construção de acusações puramente conjecturais, em grave atentado à liberdade individual. Por exemplo: todo criminoso costuma ocultar a arma do crime; a arma utilizada na tentativa de homicídio não foi encontrada; logo, o indiciado a escondeu.

(...)

Seria, com efeito, insuportável despautério que alguém pudesse ser denunciado criminalmente pela prática de um fato supostamente ocorrido: um homicídio sem cadáver, um furto sem a prova da subtração de coisa móvel, uma bigamia sem prova da celebração de novo casamento. Por isso mesmo, o Código de Processo Penal exige que a denúncia ou queixa contenha "a exposição do fato criminoso, com todas as suas circunstâncias" (art. 41). Sobre a ocorrência do crime não pode subsistir dúvida alguma, sendo claramente inepta a peça acusatória que se fundasse não em fato provado e indiscutível, mas em simples conjecturas. " 41

A própria CVM, concluiu dessa mesma forma, no Processo

Administrativo Sancionador $n^{0}$ 09/04, ocasião em que o seu Relator, Diretor Pedro Marcilio de Souza afirmou:

"71. A coerência e plausibilidade da teoria da acusação, no entanto, não são suficientes para sancionar a conduta de qualquer pessoa em um Estado de Direito. Faz-se necessário comprovar a teoria, não pela simples demonstração do resultado das operações ou pela demonstração de que a performance dos indiciados diminuiu substancialmente após a saída do indiciado Bernardo Clemente da sociedade para qual trabalhava, como fez a acusação, mas a partir de provas admitidas em direito. A coerência entre o resultado obtido e o modus operandi pressuposto pela acusação apenas demonstra a coerência de sua tese, mas não a comprova. Inexistentes esses resultados, a teoria não seria nem mesmo crível. Por esse motivo, o fato de os outros indiciados que teriam se beneficiado dessa especificação "não conforme" das ordens serem pessoas necessárias à implementação dessa especificação vai ao encontro da tese da acusação, mas também não é prova." ${ }^{42}$

${ }^{41}$ COMPARATO, Fábio Konder, Direito Público - Estudos e Pareceres, São Paulo: Saraiva, 1996, pp. 256 e 257.

${ }^{42}$ Extrato da sessão de julgamento do Processo Administrativo Sancionador CVM 09/2004. DiretorRelator: Pedro Oliva Marcilio de Sousa. Presidente da sessão de julgamento: Marcelo Fernandez Trindade. j. 20.06.2006. $\quad$ Disponível em: [http://www.cvm.gov.br/export/sites/cvm/sancionadores/sancionador/anexos/2006/20060620_PAS_09 04.pdf]. Acesso em: 25.04.2016. 
Do mesmo modo, o PAS 22/94, ocasião em que o então Diretor Luiz Antonio Campos foi acompanhado no seguinte entendimento:

\begin{abstract}
"Como me parece que não existiu, ou ao menos não restou comprovada a irregularidade apontada pela Comissão de Inquérito, absolvo todos os indiciados das imputações de prática não equitativa e manipulação de preços.

“(...) Todavia, o ponto fundamental para este tipo de questão, em tese, é que não basta qualquer indício; a existência de qualquer indício não é suficiente para ensejar a condenação. Há que se diferenciar o indício da prova indiciária, eis que, de fato, o mero indício não autoriza a condenação, mas tão-somente a prova indiciária, quando representada por indícios múltiplos, veementes, convergentes e graves, que autoriza uma conclusão robusta e fundada acerca do fato que se quer provado, respeitado, naturalmente, o princípio do livre convencimento do Juiz." ${ }^{\text {43 }}$
\end{abstract}

E, ainda, no processo PAS 2002/2405, também acompanhando voto daquele Diretor:

“(...) A questão é, portanto, do ponto de vista material e processual, absolutamente gasosa, no sentido de não ter qualquer concretude, mas apenas, com o devido respeito, conjecturas.

'A mera plausibilidade teórica de que determinada situação ocorra ou tenha ocorrido não autoriza nem acusação, que dirá condenação. $E$ a só lembrança dessa situação causa arrepios, pois todo o esforço do Estado de Direito é para se evitar possibilidades deste jaez, cujos resultados são conhecidos e deram origem, não faz tanto tempo assim, a episódios que a história prefere esquecer, como gulags e que tais.

'(...)

'E neste pedaço, imediatamente recordo-me da propositura de Arquimedes, que dizia: dá-me um ponto de apoio e uma alavanca que eu levantarei o mundo. Diria então Arquimedes, em situação como a presente: dê-se a alguém o direito de realizar conjecturas e presumir, que se condenará quem quiser. Ninguém poderá estar tranquilo, mesmo o mais honesto dos homens, porque, se for escolhido - ou mesmo sorteado - como alvo de conjecturas e presunções, será condenado. Felizmente isso não é a verdade, pelo menos à luz do processo administrativo, porque aqui se cuida essencialmente de um processo de natureza disciplinar e, como é já assentado em toda e qualquer doutrina em que se cuidou do assunto, nesse tipo de processo é fundamental a existência de provas.

\footnotetext{
${ }^{43}$ Extrato da sessão de julgamento do Processo Administrativo Sancionador CVM 22/1994. DiretorRelator: Luiz Antonio de Sampaio Campos. Presidente da sessão de julgamento: Luiz Leonardo Cantidiano. j. 15.04.2004. Disponível em: [http://www.cvm.gov.br/sancionadores/sancionador/2004/20040415_2294.html]. Acesso em: 25.04.2016.
} 
'As perplexidades e dificuldades que envolvem a aceitação de indícios como elementos suficientes a amparar uma condenação estão centradas no juízo de certeza que se exige para condenar e no princípio in dubio pro reo.

'Portanto, todo o esforço da doutrina e da jurisprudência que aceitam a condenação com base em indícios dirigiu-se para cercar a utilização de indícios da necessária segurança, como forma de conciliá-lo com o juízo de certeza e a presunção de inocência; e de se acautelar contra certos voluntarismos e evitar desvios de raciocínio. (...)

'Portanto, sempre que a questão não seja estreme de dúvidas e que dos fatos possam decorrer mais de uma explicação ou interpretação, não se pode, sob pena de afronta a regras legais e constitucionais, adotar aquela que é mais prejudicial ao acusado, afastando-se as hipóteses que lhe seriam mais benéficas, notadamente quando se trata de processo baseado exclusivamente em indícios.

(...)

'Em função destes fatos, tanto a doutrina quanto a jurisprudência já apontaram que os indícios devem ser examinados com redobrada cautela, porque, muitas vezes, sob o pretexto de haver indícios, há apenas conjecturas, suspeitas, suposições, juízos preconcebidos, preconceitos, mas que não encontram respaldo nas prova dos autos.

$(\ldots .),$.

Apesar de tantos precedentes neste sentido, não se nega que a CVM já tenha decidido de forma diversa a sua própria jurisprudência. Ocorre que, mesmo quando assim o fez, se estava diante de uma hipótese de fraude e de prestação de informação falsa à autoridade fiscalizadora ${ }^{45}$.

\footnotetext{
${ }^{44}$ Extrato da sessão de julgamento do Processo Administrativo Sancionador CVM 2002/2405. DiretoraRelatora: Norma Jonssen Parente. Presidente da sessão de julgamento: Wladimir Castelo Branco Castro. Relator do voto vencedor: Luiz Antonio De Sampaio Campos. j. 09.10.2003. Disponível em: [http://www.cvm.gov.br/export/sites/cvm/sancionadores/sancionador/anexos/2003/20031009_PAS_RJ 20022405.pdf]. Acesso em: 25.04.2016.
}

${ }^{45}$ Nesse sentido, segue trecho do voto do Diretor Relator Sérgio Weguelin: “(...) Não pretendo negar este entendimento. Mas, a meu ver, esta prova pode ser extraída das características da operação e da existência de um mecanismo que obscurece seu beneficiário final. Isto é, por si só, prova que houve acesso à informação, ainda que se desconheça como os defendentes chegaram a tal informação.

(...) a análise desses mesmos casos revela que um dos principais elementos levados em consideração na apreciação das provas sobre os casos de 'insider trading' é a existência de subterfúgios ou mecanismos fraudulentos relacionados à operação (uso de contas 'offshore' e fornecimento às autoridades de informações que posteriormente se revelaram inverídicas, por exemplo). O uso da Calmaria como 'laranja' é um claro exemplo desta espécie de artifício." (da sessão de julgamento do Processo Administrativo Sancionador CVM 24/05. Diretor-Relator: Sergio Weguelin. Presidente da sessão de julgamento: Maria Helena dos Santos Fernandes de Santana. j. 07.10.2009. Disponível em: http://www.cvm.gov.br/sancionadores/sancionador/2008/20081007_2405.html]. Acesso em: 18.05.2016. 
O Conselho de Recursos do Sistema Financeiro Nacional, também já manifestou seu entendimento no mesmo sentido ao julgar o Recurso 8253. Fundamentou sua decisão de absolvição justamente porque os indícios apresentados no processo "não se robusteceram com provas que os tirassem da dimensão hipotética", como se vê do trecho do voto vencedor do conselheiro Johan Albino Ribeiro, abaixo transcrito:

\begin{abstract}
"Não me convenci de que houve o uso de informação privilegiada. O Sr. Walter Appel não participou diretamente das negociações junto ao consórcio de privatização da COPEL, portanto não estaria caracterizado o chamado insider direto. Para o insider indireto teria que haver uma prova mais efetiva, como, aliás, foi o entendimento da CVM, com relação aos demais indiciados, absolvidos por falta de provas.

No entender da CVM, fortes indícios, como a proximidade dos locais de trabalho do Sr. Walter Appel e do Sr. Venilton Tadini, ou o fato de que a cada 15 dias o Sr. Walter Appel se reunia com todas as áreas do Grupo Fator, inteirando-se de todos os assuntos, teriam sido suficientes para justificar a decretação do uso da informação privilegiada. Mas esses dados estão no plano conjetural e não se robusteceram com provas que os tirassem da dimensão hipotética". ${ }^{46}$
\end{abstract}

Como visto acima, doutrina e jurisprudência caminharam para a conclusão de que não é qualquer indício que autoriza a condenação e, mais ainda, nem mesmo a pluralidade de indícios necessariamente autoriza a condenação. A experiência jurídica cuidou de qualificar a condenação com base em indícios e, para tanto, passou a exigir que para ensejar a condenação, os indícios devem ser graves, plurais, convergentes e concludentes.

E, diga-se, a razão de todos esses requisitos de validade da prova indiciária residem no fato de se exigir, para qualquer condenação, um juízo essencialmente de certeza:

\footnotetext{
${ }^{46}$ BRASIL. Conselho de Recursos do Sistema Financeiro Nacional. Recurso $n^{\circ} 8253$, referente ao Processo Administrativo Sancionador 18/01. Conselheiro-Relator: Felisberto Bonfim Pereira. julgado em 27.02.2008. Brasília: Ministério da Fazenda, CRSFN, 2008. Disponível em [http://www.bcb.gov.br/.../download.asp?arquivo=ACÓRDÃO CRSFN 8308-08.doc]. Acesso em 17.05.2016
} 
"Nenhuma pena pode ser aplicada sem a mais completa certeza dos fatos. A pena, disciplinar ou criminal, atinge a dignidade, a honra e a estima da pessoa, ferindo-se gravemente no plano moral, além de representar a perda de bens ou interesses materiais". ${ }^{47}$

Havendo dúvida, seja quanto à materialidade ou quanto à autoria, por menor que seja, a absolvição se impõe. É o que explica o Desembargador aposentado AdALBERTo José Q. T. DE CAMARGO ARANHA:

"A sentença condenatória criminal somente pode vir fundada em provas que conduzam a uma certeza. Até mesmo a alta probabilidade servirá como fundamento absolutório, pois teríamos tão-só um juízo de incerteza que nada mais representa que não a dúvida quanto à realidade.

Como disse Nélson Hungria, a dúvida é sinônimo de ausência de prova. E finaliza Pannaim: "Se há dúvida, é porque a prova não está feita.

Concluindo: a condenação criminal somente pode surgir diante de uma certeza quanto à existência do fato punível, da autoria e da culpabilidade do acusado. Uma prova deficiente, incompleta ou contraditória gera a dúvida e com ela a obrigatoriedade da absolvição, pois milita em favor do acionado criminalmente uma presunção relativa de inocência." 48

Nesse sentido, além da doutrina e jurisprudências já citadas, o Superior Tribunal de Justiça:

"A condenação com base em indícios somente terá lugar, conforme advertência da doutrina, quando a relação entre o fato demonstrado (residência na república de estudantes) e o fato que se infere (tráfico de drogas), 'seja tão certo e evidente de modo a não ser possível uma conclusão diversa daquela que se chega'." 49.

Tanto a doutrina quanto a jurisprudência são fartas e apontam que indícios devem ser examinados com redobrada cautela:

\footnotetext{
${ }^{47}$ FRAGOSO, Heleno Cláudio, Jurisprudência Criminal, vol. 2, Forense p. 446 - 532.

${ }^{48}$ ARANHA, Adalberto José Q. T. de Camargo. Da prova no processo penal. $7^{\circ}$ Ed. São Paulo: Saraiva, 2006. p.84.

${ }^{49}$ BRASIL. Superior Tribunal de Justiça (STJ). Habbeas Corpus $n^{\circ}$ 8.928/SP - Órgão Julgador: Sexta Turma. Relator: Min. Fernando Gonçalves. São Paulo. Publicação no DJ em 24.05.1999, p. 532.
} 
"Insista-se, pois, em alertar que a prova indiciária - conquanto seja uma prova de raciocínio e, como tal, capaz de iluminar os caminhos na busca da verdade e da certeza - é um tipo de prova cuja articulação exige grande perspicácia, atenção e prudência, sendo realmente difícil o domínio de sua técnica. Qualquer deslize ou precipitação no trânsito deste cipoal de múltiplas e variadas circunstâncias pode levar à areia movediça dos sofismas, viciando as conclusões e propiciando lamentáveis enganos e erros judiciários." 50

Não por outra razão, aliás, a CVM, no voto do seu então presidente Marcelo Trindade no PAS 35/00, reconheceu que, havendo dúvida, impõe-se a absolvição:

"Quanto aos investidores que atuaram comprando e vendendo ações da CFR, tenho muitíssimas dúvidas, mas sou obrigado pela lei a dormir para sempre com elas, tendo em vista minha ignorância quanto ao destino final desses papéis. A investigação realizada pela Comissão de Inquérito não logrou êxito em demonstrar o conluio entre essas pessoas e, portanto, a meu juízo, não há elementos para condenar os investidores estrangeiros e seus representantes. Faço isto, insisto, em homenagem ao princípio do in dubio pro réu" ${ }^{51}$.

Os entendimentos demonstrados acima corroboram tudo o que se discutiu nesta seção: se não houver elementos suficientemente robustos e estremes de dúvidas quanto à autoria e materialidade de certa irregularidade não se admite a condenação de quem quer que seja.

\subsection{Diferença entre punibilidade Insider primário, Insider secundário ou Insider de mercado}

Agora, se passa a abordar mais profundamente o conceito de insider secundário em contraponto com o insider primário.

\footnotetext{
${ }^{50}$ COELHO, Walter. Prova Indiciária em Matéria Criminal. Porto Alegre: Sérgio Antônio Fabris, 1996, pp. $59-532$.

${ }^{51}$ Extrato da sessão de julgamento do Processo Administrativo Sancionador CVM 35/2000. DiretorRelator: Wladimir Castelo Branco Castro. Presidente da sessão de julgamento: Marcelo Fernandez Trindade. j. 12.04.2005. Disponível em: [http://www.cvm.gov.br/export/sites/cvm/sancionadores/sancionador/anexos/2005/20050412_PAS_35 00.pdf]. Acesso em: 25.04.2016.
} 
Quando um terceiro negocia em posse de uma informação relevante obtida através de um nexo profissional ou pessoal que possua com um informante, alguém que esteja inteirado das decisões da companhia, com o ânimo de utilizá-la em benefício próprio, este é conhecido como tippee. No tocante a essa classificação são necessárias algumas considerações quanto o alcance do conceito, de forma que não se amplie demasiadamente a conduta.

Os pontos mais importantes da caracterização do insider secundário são definidos como: (i) o ônus da prova do ato ilícito é do órgão regulador; (ii) a efetiva negociação no mercado de valores deve ter ocorrido única e exclusivamente por força do conhecimento advindo da informação recebida e da consciência de que tal fato ainda não havia sido divulgado ao mercado (dolo); e (iii) é necessária a confirmação de que havia um relacionamento entre aquele que concedeu a informação sigilosa (tipper) e aquele que a recebeu (tippee) ${ }^{52}$.

Diante desses aspectos diferenciadores, resta clara, a importância da distinção entre o insider primário e o secundário. $\mathrm{O}$ insider primário faz referência aos agentes que apresentam um dever de ética e lealdade para com a companhia, além de possuírem acesso diferenciado e facilitado a seus atos e fatos devido a posição que nela ocupam, enquanto que no insider secundário, como visto, o agente negocia com a informação recebida pelo informante, por essas razões o tratamento jurídico dessas duas classificações precisa ser totalmente diferenciado.

\footnotetext{
${ }^{52}$ ROSSI, Lívia Trabulsi. "Fundamentos para a constituição de prova indiciária em casos de Insider Trading de Mercado". Revista de Direito Bancário e do Mercado de Capitais, ano 18, n. 69, São Paulo: Revista dos Tribunais, jul./set. 2015. pp. $123-148$.
} 
A Lei das S/A em seus artigos dispõe sobre a presunção de culpa dos administradores quando da violação das normas legais e estatutárias. A mesma presunção relativa, que admite prova em contrário, pode ser aplicada em relação ao insider trading, visto que tal prática também está elencada como ilícita na $1 \mathrm{ei}^{53}$.

O voto do Diretor Otavio Yazbek na sessão de julgamento do PAS 13/2009, exemplifica bem o tema:

\begin{abstract}
“(...) nos casos envolvendo insiders secundários, a utilização de indícios na construção da peça acusatória e na eventual condenação dos acusados mostra-se não só como um caminho natural, mas, muitas vezes, como o único caminho a ser seguido; isso porque penso que a prova definitiva e irrefutável da prática de insider de mercado é bastante complexa, exceto se, de alguma forma, o vínculo ficar claramente evidente, como ocorreria na hipótese de haver uma confissão, por exemplo.

Entendo, assim, possível que uma condenação seja baseada em prova indiciária, formada por um conjunto de indícios sérios, consistentes e convergentes, e respeitado o princípio do livre convencimento motivado do julgador e essas provas indiciárias são, inclusive, reconhecidas expressamente pelo art. 239 do CPP". ${ }^{54}$
\end{abstract}

Bem se sabe que as presunções relativas ao conhecimento e relevância da informação privilegiada, no que concernem aos diversos participantes do mercado, possuem níveis completamente diferentes de exigência, exatamente porque existem diversas categorias de insiders. Essas diferenças repercutem nas diferentes obrigações legais existentes para cada parte no que concerne o dever

\footnotetext{
${ }^{53}$ RUY, Fernando Estevam Bravin. Direito do investidor consumidor no mercado de capitais e nos fundos de investimento. Rio de Janeiro: Lumen Juris, 2010. p.178.

${ }^{54}$ Extrato da sessão de julgamento do Processo Administrativo Sancionador CVM 13/2009. DiretoraRelatora: Luciana Dias. Presidente da sessão de julgamento: Maria Helena dos Santos Fernandes de Santana. j. 03.04.2012. Disponível em: [www.cvm.gov.br/port/inqueritos/2011/rordinario/inqueritos/IA\%2013-09\%20Sadia.asp]. Acesso em: 26.02.2015.
} 
de divulgar ato ou fato relevante e de sigilo, e principalmente no uso da informação privilegiada.

Como visto anteriormente, a Instrução CVM 358/02 dispõe que o agente de mercado não é obrigado por lei ao dever de sigilo ou de informar, o que acarreta a inaplicabilidade de quaisquer presunções quanto a sua atuação, tanto de conhecimento da informação privilegiada, quanto da noção de que se trata de informação sigilosa. ${ }^{55}$

No âmbito da CVM, a autarquia tem consolidado o entendimento de que não vigora qualquer presunção sobre a posse de informação privilegiada nos casos de insider secundário, sendo ônus da acusação comprovar a negociação indevida.

A principal peça do insider trading sem dúvidas é a informação. Ela pode existir, ou não, no plano material ou apenas estar presente no plano das ideias. De ambas as formas, o conhecimento a respeito da informação estará restrito à consciência do agente, de maneira que se torna muito difícil a comprovação sem que o agente a externalize e, portanto, a prova cabal do insider se torna impossível.

O Diretor Eli Loria destacou em seu voto proferido no âmbito julgamento do Processo Administrativo Sancionador 13/2009 o que segue:

"Para a resolução de casos em que a prova direta torna-se impossível, a prova indiciária é fundamental, porquanto a solução somente seria viável na hipótese em que a intenção dos acusados pudesse ser pesquisada e afirmada, independentemente, é óbvio, de confissão.

\footnotetext{
${ }^{55}$ ROSSI, Lívia Trabulsi. "Fundamentos para a constituição de prova indiciária em casos de Insider Trading de Mercado". Revista de Direito Bancário e do Mercado de Capitais, ano 18, n. 69, São Paulo: Revista dos Tribunais, jul./set. 2015. pp. 123 - 148
} 
Entretanto, como qualquer meio de prova, um indício, ou mesmo um conjunto de indícios sem consistência, não é suficiente para a condenação. A robustez deste conjunto de indícios é salutar para que se tenha o fato por provado."

Consequentemente, o reconhecimento da prática do insider trading ocorre pela verificação dos indícios que confluem de maneira a indicar a prática do ilícito, os quais, formando um conjunto robusto de indicativos, constituem a prova indiciária, essa sim, suficiente para o convencimento do julgador.

A própria CVM já definiu o conceito de prova indiciária em diversas oportunidades, entendendo que por ser equivalente a qualquer outro meio de prova, dado o princípio do livre convencimento do julgado. O importante a ser analisado é que os indícios sejam convergentes e suficientes para sustentar a condenação, como entendeu o então Diretor Luiz Antonio Sampaio Campos, no Processo Administrativo Sancionador CVM no 22/94:

\footnotetext{
“ $\{A\}$ existência de qualquer indício não é suficiente para ensejar a condenação. Há que diferenciar o indício da prova indiciária, eis que, de fato, o mero indício não autoriza a condenação, mas tão somente a prova indiciária, quando representada por indícios múltiplos, veementes, convergentes e graves, que autoriza uma conclusão robusta e fundada acerca do fato que se quer provado. ${ }^{, 57}$
}

\footnotetext{
${ }^{56}$ Extrato da sessão de julgamento do Processo Administrativo Sancionador CVM 13/2009. DiretorRelator: Eli Loria. Presidente da sessão de julgamento: Maria Helena dos Santos Fernandes de Santana. j. 13.12.2011. Disponível em: [http://www.cvm.gov.br/sancionadores/sancionador/2011/20111213_1309.html]. Acesso em: 05.05.2016.

${ }^{57}$ Extrato da sessão de julgamento do Processo Administrativo Sancionador CVM 24/05. DiretorRelator: Sergio Weguelin. Presidente da sessão de julgamento: Maria Helena dos Santos Fernandes de Santana. j. 07.10.2009. Disponível em: http://www.cvm.gov.br/sancionadores/sancionador/2008/20081007_2405.html]. Acesso em: 18.05.2016.
} 
Norma JONSSEN PARENTE, em seu livro Aspectos Jurídicos do Insider Trading, explica, ainda, que tais provas poderão ser consideradas:

"normas da experiência comum, subministradas pela observação do que ordinariamente acontece (prova baseada na experiência - denominada prova prima (acie)" ${ }^{58}$

O entendimento da CVM caminha no mesmo sentido. Em diversas ocasiões decidiu pela validade da prova indiciária na comprovação da prática do insider secundário por agentes do mercado.

O voto do Diretor Otavio Yazbek, no processo PAS 13/2009, muito bem exemplifica o entendimento já consolidado pela autarquia.

“(...) nos casos envolvendo insiders secundários, a utilização de indícios na construção da peça acusatória e na eventual condenação dos acusados mostra-se não só como um caminho natural, mas, muitas vezes, como o único caminho a ser seguido; isso porque penso que a prova definitiva e irrefutável da prática de insider de mercado é bastante complexa, exceto se, de alguma forma, o vínculo ficar claramente evidente, como ocorreria na hipótese de haver uma confissão, por exemplo.

Entendo, assim, possível que uma condenação seja baseada em prova indiciária, formada por um conjunto de indícios sérios, consistentes e convergentes, e respeitado o princípio do livre convencimento motivado do julgador e essas provas indiciárias são, inclusive, reconhecidas expressamente pelo art. 239 do CPP. ${ }^{59}$

E ainda, como se o entendimento da referida autarquia não fosse suficiente, o Código de Processo Penal em seu art. 239 constante do Título Prova do referido diploma, define indício como:

\footnotetext{
${ }^{58}$ PARENTE, Norma Jonssen. Aspectos jurídicos do insider trading. CVM: 1978. Disponível em: [http://www.cvm.gov.br/export/sites/cvm/menu/acesso_informacao/serieshist/estudos/anexos/Aspectos -Juridicos-do-insider-trading-NJP.pdf]. Acesso em: 05.05.2016.

${ }^{59}$ Extrato da sessão de julgamento do Processo Administrativo Sancionador CVM 13/2009. DiretorRelator: Eli Loria. Presidente da sessão de julgamento: Maria Helena dos Santos Fernandes de Santana. j. 13.12.2011. Disponível em: [http://www.cvm.gov.br/sancionadores/sancionador/2011/20111213_1309.html]. Acesso em: 05.05.2016.
} 
"circunstância conhecida e provada, que, tendo relação com o fato, autorize, por indução, concluir-se a existência de outra ou outras circunstâncias."

Dessa forma fica clara a diferença entre um indício e uma prova indiciária. A condenação que tem por base apenas um indício isolado não é permitida pelo ordenamento jurídico. Apenas quando um conjunto de indícios graves e convergentes acerca de um fato forma uma prova indiciária é que esta pode ser utilizada como argumento para uma condenação.

E esse conjunto de provas é justamente o fator diferenciador na punibilidade do insider primário e do secundário. Isto porque, no caso dos profissionais de mercado de capitais, a verificação da prática de insider trading é especialmente desafiadora justamente por causa das características de suas atividades, que envolvem contato com diversos players, seja de companhias, consultoria ou outros agentes de mercado, negociação com valores mobiliários de inúmeras companhias, recebimento e cruzamento de informações vindas de diversas fontes, bem como a exposição a boatos de mercado. ${ }^{60}$

Uma vez que inexiste uma prática ou um ato que cabalmente comprove a posse da informação privilegiada e seu uso com a intenção de auferir vantagem, somente por meio da verificação de um conjunto de ações e fatos pode-se presumir que, de fato, a operação sob investigação constituiu insider trading. No entanto, inexistem, também, normas que guiem em quais e quantos fundamentos fáticos pode o julgador se apoiar para justificar uma condenação.

${ }^{60}$ ROSSI. op. cit. pp. 132. 


\subsubsection{Insider primário, o elemento subjetivo do art. 13 da Instrução CVM $n^{\circ} 358 / 02$, indícios e presunções}

Apesar de, como dito posteriormente, ser dever dos administradores divulgar aos investidores com transparência e clareza os fatos relevantes ao desenvolvimento da companhia, existem ocasiões em que se deve agir ao revés. Isto é, em alguns momentos é necessário que não se revele ao mercado, por algum tempo, informações que embora sejam relevantes, durante o período de sigilo devem ser de acesso exclusivo de uns membros da sociedade.

É nesse momento que se impõe àqueles que a possuem (administradores, controladores, entre outros) o dever de abster-se de divulgá-la precocemente ou utilizá-la ilicitamente para obter vantagens. ${ }^{61}$ Tal dever decorre do princípio da igualdade de acesso às informações, que abrange todos os acionistas e cujo objetivo se traduz na proteção dos investidores e na higidez do próprio mercado de valores.

Portanto, a não divulgação de informação relevante sigilosa é um dos deveres impostos aos administradores de sociedades anônimas, conforme dispõe o art. 155 da Lei 6.404/1976, em seu $§ 1^{\circ}$.

\footnotetext{
"Art. 155. O administrador deve servir com lealdade à companhia e manter reserva sobre os seus negócios, sendo-lhe vedado:

I - usar, em benefício próprio ou de outrem, com ou sem prejuízo para a companhia, as oportunidades comerciais de que tenha conhecimento em razão do exercício de seu cargo;

II - omitir-se no exercício ou proteção de direitos da companhia ou, visando a obtenção de vantagens, para si ou para outrem, deixar de aproveitar oportunidades de negócio de interesse da companhia;

III - adquirir, para revender com lucro, bem ou direito que sabe necessário à companhia, ou que esta tencione adquirir.
}

\footnotetext{
${ }^{61}$ DIAS, Amanda Tayar Duarte; "Questões atuais envolvendo o Insider Trading”. Revista de Direito Bancário e do Mercado de Capitais; ano 12, n. 45, São Paulo: Revista dos Tribunais, jul./set. 2009. p. 128
} 
$\S 1^{\circ}$. Cumpre, ademais, ao administrador de companhia aberta, guardar sigilo sobre qualquer informação que ainda não tenha sido divulgada para conhecimento do mercado, obtida em razão do cargo e capaz de influir de modo ponderável na cotação de valores mobiliários, sendo-lhe vedado valer-se da informação para obter, para si ou para outrem, vantagem mediante compra ou venda de valores mobiliários.

$\S 2 .^{\circ}$. O administrador deve zelar para que a violação do disposto no $\S 1^{\circ}$ não possa ocorrer através de subordinados ou terceiros de sua confiança.

$\S 3^{\circ}$. A pessoa prejudicada em compra e venda de valores mobiliários, contratada com infração do disposto nos $\S 1^{\circ}$ e $2^{\circ}$, tem direito de haver do infrator indenização por perdas e danos, a menos que ao contratar já conhecesse a informação. (...).”

Também na esfera penal, o crime de uso indevido de informação privilegiada é punido com pena de 1 a 5 anos e multa de até 3 vezes o valor do lucro obtido e está previsto na Lei 6.385/1976, em seu art. 27-D, inserido através da Lei 10.303/2001, como visto anteriormente.

Consequentemente, conforme observado pelos dispositivos legais, a transgressão ao dever de sigilo, pode levar a configuração do ilícito conhecido como insider trading. Diante disto, tal crime é definido como o uso de informações privilegiadas obtidas única e exclusivamente em decorrência do cargo exercido ou em virtude do exercício da profissão, uma vez que o insider conhece a companhia e possui acesso ao funcionamento de seus negócios. ${ }^{62}$

Como ainda não foram revelados ao mercado, aquele que tem conhecimento desses fatos antes dos outros investidores pode negociar com as ações da companhia e se beneficiar com a sua eventual alta, em detrimento dos outros investidores que, por sua vez, poderão buscar ressarcimento por perdas e danos caso sintam-se prejudicados.

Isto posto, atualmente, nota-se um alargamento do conceito de insider primário. Pensando nisto, a Iosco elaborou o conceito de "insider termporário",

\footnotetext{
${ }^{62}$ Idem.
} 
que reúne todos que estiveram dentro da companhia, participando de suas negociações, durante o período em que ocorreram as deliberações acerca do fato relevante sigiloso.

Nesse sentido, o trecho de Relatório publicado pela Iosco, traz a importância de haver uma distinção entre o insider e o tippee, mas sugere a inclusão dos temporary insiders na primeira categoria:

\begin{abstract}
"In definitions of insiders, a distinction is usually drawn between two categories of insiders: primary insiders and secondary ones. Such a distinction is justified for a number of reasons. First, primary insiders get information from its source and have the necessary knowledge to assess the materiality of the information. Secondly, they are expected to understand the consequences of trading on confidential information. Hence, the sanctions imposed on primary insiders are usually much harsher than those imposed on secondary ones. (...)

Definitions of 'primary insider' generally include members of management and the supervisory or administrative bodies of the issuer. This definition is sometimes expanded to include employees of the company and those who provide services to the issuer (including outside lawyers, accountants and financial advisers). (...)

The concept of primary insiders under US regulations relates to the fiduciary duty of particular persons to the relevant corporation, such as officers, directors, and employees. However, such a fiduciary duty can be acquired by persons who provide services to the corporation, like outside lawyers, consultants, investment bankers or others (so called temporary or constructive insiders (see section 1.2.1.1.), provided the corporation expects them to keep the information confidential. Definitions of primary insider should encompass the officers in the company generating the inside information, as well as any outside professional service providers having access to inside information. In jurisdictions where the employees of the securities regulator have access to inside information, they should be included within this definition. To facilitate the enforcement of insider trading regulations, a primary insider should have the burden of proof to negate a presumption that he had knowledge of inside information." ${ }^{, 63}$
\end{abstract}

Desse modo, a caracterização da conduta típica a informação privilegiada deverá ser, necessariamente, sigilosa e relevante, ou seja, a informação não deve ser passível de ser obtida por meios acessíveis ao público em geral, de maneira

\footnotetext{
${ }^{63}$ IOSCO, Internacional Organization of Securities Comissions, Insider Trading. How Jurisdictions Regulate It. March/2003. Disponível em: [https://www.iosco.org/library/pubdocs/pdf/IOSCOPD145.pdf]. Acesso em 16.05.2016.
} 
que, caso já tenha sido disseminada, mesmo que de forma irregular, já não será mais sigilosa.

É ainda, pertinente afirmar que os dois elementos básicos para a caracterização da prática de insider trading em seu sentido clássico são a existência de um relacionamento profissional que dê acesso direto ou indireto a informações absolutamente sigilosas da companhia; e o uso de informação sigilosa com a finalidade de obter vantagem em função do desconhecimento de tal fato pelo mercado.

Cabe ressaltar que todos aqueles que podem ser tipificados como insiders primários possuem cargos que lhes possibilitam o acesso irrestrito às decisões e às negociações da companhia. Por tal motivo, caso sejam investigados pela prática do ilícito têm o ônus de provar sua inocência, fato de suma importância para a distinção entre o insider primário e o tippee.

Por sua vez, a Instrução CVM 358/2002, em seu artigo 13, também traz a distinção de presunções entre o insider primário e o secundário. O caput do artigo apresenta uma presunção absoluta de determinados agentes, que por possuírem informações privilegiadas estariam incorrendo em crime de insider. Note ainda que, o parágrafo $1^{\mathrm{o}}$ do dispositivo trata de uma presunção relativa, cabendo, pois, à acusação dos agentes compreendidos no parágrafo o ônus de provar que eles tiveram acesso a determinadas informações privilegiadas e que fizeram uso das mesmas em benefício particular. 


\subsubsection{Insider de mercado e a prova indiciária}

Em consonância com o que está sendo estudado entremos no âmbito dos insiders de mercado e a forma como eles têm sido investigados e condenados pela CVM nos últimos anos.

O insider secundário ocorre quando um terceiro, alheio ao funcionamento interno da companhia, obtém informações através de alguém que possui acesso em função de sua posição na empresa e divulga tais informações, que deveriam permanecer em sigilo, para obter vantagens ilícitas.

Dessa forma, o terceiro que negocia a informação em virtude de um nexo profissional ou pessoal que possua com alguém que esteja inteirado das decisões da companhia e tem o ânimo de utilizá-la para se beneficiar ilicitamente é conhecido como tippee. Em relação a esse tipo de ilícito, se faz necessário formular algumas considerações para que se determine o alcance de tal conceito, de forma que não sejam caracterizadas como criminosas situações que não devem ser punidas.

O Diretor Marcelo Trindade, no julgamento do PAS CVM 04/2004, frisou que quando se trata de terceiros, alheios aos negócios da companhia não há espaço para presunções, isto é, a comprovação da autoria concreta do indiciado é essencial nesses casos:

"Tradicionalmente se faz a distinção entre o insider primário, administrador da companhia ou terceiro com acesso direto às informações da companhia, sobre os quais recai a presunção iuris tantum de que detinham a informação, e o terceiro que negocia de posse da informação privilegiada, mas não é insider, e em relação ao qual é preciso provar o conhecimento dos fatos revelados ao mercado." ${ }^{64}$

\footnotetext{
${ }^{64}$ Extrato da sessão de julgamento do Processo Administrativo Sancionador CVM 04/2004. DiretorRelator e Presidente da sessão de julgamento: Marcelo Fernandez Trindade. j. 28.06.2006. Disponível
} 
No insider secundário também se faz necessário analisar o requisito do dolo, que é essencial para a responsabilização do sujeito pela negociação de ações no mercado, em posse de informações sigilosas e relevantes, ainda não divulgadas ao mercado.

Além do dolo específico, outro requisito que deve ser analisado é o relacionamento entre quem obteve e quem forneceu a informação privilegiada. Dessa forma, é essencial para que haja a responsabilização do investigado por tal prática, que tenha existido o dolo por ambas as partes. Ou seja, tanto o tipper quanto o tippee devem ter trocado informações tendo conhecimento da ilegalidade de sua divulgação.

Para fins práticos, um garçom que escuta uma conversa entre dois clientes e decide negociar com base na informação obtida por esse meio, não estaria cometendo um ato irregular, visto que não possui dolo de obter vantagem contra os demais investidores, muito menos a consciência de que essa informação ainda não foi divulgada ao mercado e que deveria ser. Exatamente por isso que, para a configuração do insider é necessário que a acusação comprove a existência de nexo profissional ou pessoal entre os agentes, aqueles que passam a informação e aquele que a recebe.

Apesar disso, é importante ressaltar que embora o investidor não deva ser punido pelo mero boato de mercado, o responsável pelo vazamento, no entanto, poderá sofrer alguma punição desde que fosse seu dever impedir que tal fato se tornasse público, em decorrência de sua função na companhia:

em: [http://www.cvm.gov.br/sancionadores/sancionador/2006/20060628_0404.html]. Acesso em: 15.05.2016. 
"Assim, o conhecimento ocasional da informação por razões outras que não a do exercício de alguma profissão ou do controle de informação relevante é de difícil configuração. Se terceiro souber em uma reunião social que haverá a incorporação de determinada companhia ou a venda de seu controle, não tendo essa mesma pessoa qualquer acesso de natureza profissional e permanente (controlador) a tal informação, não poderá ser considerada como tippee. Se, com efeito, a informação relevante vazou além do âmbito dos controladores e dos envolvidos profissionalmente com ela, os terceiros ocasionalmente informados não poderão ser considerados insiders. Caberá, nesse caso, diretamente ao administrador a responsabilidade por não ter mantido a reserva necessária sobre o fato relevante, a ponto de este ter vazado para o âmbito meramente social." 65

Isso ocorre porque os administradores, diretores e controladores possuem deveres fiduciários perante a companhia e, exatamente por isso, devem ser responsabilizados quando da não publicação de fato relevante ou quando ocorre o vazamento de informações sigilosas.

Por isso, é requisito essencial para configuração do crime de insider de mercado o dolo por parte do informante e do tippee, no entanto, sua ausência nem sempre impede a responsabilização do informante quando este for alguém que, em função do exercício da profissão, possui o dever de zelar pelo sigilo das informações relevantes ainda não divulgadas ao mercado, sendo responsabilizado quando, ainda que por negligência, permitir que pessoas alheias ao âmbito da companhia tenham acesso a elas. ${ }^{66}$

\footnotetext{
${ }^{65}$ CARVALHOSA; EIZIRIK, op. cit. p. 323.

${ }^{66}$ DIAS, op. cit. p. 144.
} 


\section{Julgados na CVM sobre o tema}

Conforme mencionado anteriormente, verifica-se que, apesar do combate ao insider estar presente nas esferas civil, penal e administrativa, é muito mais intenso na esfera administrativa, tendo a CVM como o órgão regulatório responsável.

Por esta razão, é de extrema importância o estudo e desenvolvimento das discussões referidas em alguns julgados envolvendo os insiders primários e insiders secundários que contribuíram para a construção da legislação de combate ao uso de informação privilegiada vigente em nosso país.

\subsection{Caso Credit Suisse/Terna - PAS n RJ 2010/4206}

O processo $^{67}$ foi instaurado para apurar eventual irregularidade na negociação com units da Terna Participações S.A. (“Terna”), em suposta infração ao art. 13 da Instrução CVM 358/02. O banco Credit Suisse Securities (USA) LLC ("Credit Suisse USA”) foi acusado pela prática de insider primário pela Comissão de Inquérito.

Para o estudo do caso é preciso analisar uma breve cronologia de fatos. Considerando que no dia 23.04.2009 foi divulgado fato relevante ao mercado sobre a operação de venda da Terna e que na véspera, dia 22.04.2009, o Credit Suisse USA teria negociado units de emissão da Terna, a Comissão de Inquérito entendeu que estaria diante de uma possível infração ao disposto no art. 13 da

\footnotetext{
${ }^{67}$ Processo Administrativo Sancionador CVM RJ 2010/4206. Diretor-Relator: Alexsandro Broedel Lopes. Presidente da sessão de julgamento: Maria Helena dos Santos Fernandes de Santana. j. 23.08.2011. Disponível [http://www.cvm.gov.br/export/sites/cvm/sancionadores/sancionador/anexos/2011/20110823_PAS_RJ 20104206.pdf]. Acesso em: 17.05.2016.
} 
Instrução 358/02 da CVM, tendo em vista que tal negociação teria ocorrido no período de vedação.

Apesar de a própria acusação não ter verificado nos negócios realizados indícios significativos de insider trading, dado o pequeno volume negociado, entendeu ser necessária uma investigação mais profunda de sua atuação pelo fato da instituição ter participado diretamente nas negociações.

Nesse contexto, a defesa alegou que a Comissão de Inquérito não teria conseguido provar o acesso à informação, uma vez que deixou de realizar as investigações necessárias para averiguar se, de fato, os funcionários do banco teriam tido acesso a informações privilegiadas ao participar da elaboração do fairness opinion da Terna, ou, ainda, se os responsáveis pela decisão de negociar as units da Terna possuíam tais informações.

Dessa forma, ainda segundo a defesa, os funcionários que trabalharam na elaboração do fairness opinion não eram os mesmos responsáveis pelos negócios com as units da Terna, nem mesmo participavam da área responsável por esse tipo de decisão.

A acusação, baseada em meras suposições, concluiu que dois funcionários emprestados pelo Credit Suisse USA teriam tido acesso à informação e a teriam transmitido aos responsáveis pelas operações.

Em resposta, a defesa apresentou quatro contraindícios de que a operação teria sido realizada de maneira irregular: (i) os funcionários que tiveram acesso a informação privilegiada não faziam parte da área do Credit Suisse USA que autorizou a operação; (ii) a negociação foi realizada para dar liquidez ao cliente 
motivo que não se relaciona com a suposta detenção de informação privilegiada; (iii) a negociação resultou em prejuízo para o acusado e (iv) a própria acusação reconhece que a negociação não possuía a finalidade de obter vantagem indevida.

Ainda no âmbito da defesa, outro argumento trazido foi o de que o disposto no $\S 1^{\circ}$ do art.13 da Instrução CVM 358/02 não seria uma vedação absoluta, mas que dependeria da verificação de culpabilidade do agente. Dessa forma, seria necessário avaliar se a operação se revestiria de fundamentação econômica ou de outro tipo de motivação forte, que elidiria a infração prevista.

O requisito de auferir vantagem na negociação também precisaria ser observado, visto que este é o elemento subjetivo do tipo previsto no citado artigo. A interpretação do dispositivo de outra maneira seria admitir que a CVM teria extrapolado sua função normativa alterando o expressamente previsto no art. $155 \S 4^{\circ}$ da Lei das S/A.

A respeito da controvérsia existente quanto à legalidade do art. 13 da ICVM 358/02, o ex-Diretor da CVM Alexsandro Broedel, Relator do processo em questão, considerou em seu voto:

"E é exatamente esse o objetivo da Instrução CVM no 358/02: trata-se de norma que visa a manter a higidez e a confiança do mercado, vedando a possibilidade de negócios por aqueles que detêm, antecipadamente, informação relativa a ato ou fato relevante. A meu ver, portanto, não há que se discutir acerca da legalidade da vedação contida no art.13 e parágrafos da Instrução CVM n ${ }^{0} 358 / 02$. Mas isso não significa que a acusação esteja desincumbida de, em cada caso, comprovar o seu descumprimento, ainda que mediante a utilização de prova indiciária. A defesa, por sua vez, sempre poderá apresentar todas as provas cabíveis para demonstrar que não houve o descumprimento da norma. Isso é evidente, pois decorre dos princípios 
do contraditório e da ampla defesa, que norteiam todo e qualquer processo administrativo. ${ }^{\circ 8}$

Adiante em seu voto, o Relator considerando incontroverso o fato de a negociação de units da Terna ter ocorrido um dia antes da publicação do fato relevante ao mercado, afirmou que os contraindícios trazidos pela defesa seriam provas suficientes para o firmar entendimento de que a data da negociação, véspera da publicação do fato relevante, não teria passado de mera coincidência. Tendo em vista que, teria ocorrido apenas para atender as necessidades de um cliente, não havia qualquer intenção do Credit Suisse USA em negociar ou tampouco obter vantagem com a negociação.

Dessa forma, votou pela desconstrução da acusação formulada e concluiu pela absolvição do acusado.

\subsection{Caso Bahema - PAS n 24/2005}

O presente processo $^{69}$ foi instaurado para apurar potencial uso de informação privilegiada por pessoas tidas como direta ou indiretamente relacionadas a aquisição de ações de emissão da Bahema Equipamentos S.A. ("Bahema" ou "Companhia") durante o curso de negociações, não divulgadas ao público em geral, envolvendo o controle da Companhia.

\footnotetext{
${ }^{68}$ Extrato da Sessão de julgamento do Processo Administrativo Sancionador CVM RJ 2010/4206. Diretor-Relator: Alexsandro Broedel Lopes. Presidente da sessão de julgamento: Maria Helena dos Santos Fernandes de Santana. j. 23.08.2011. Disponível em: [http://www.cvm.gov.br/export/sites/cvm/sancionadores/sancionador/anexos/2011/20110823_PAS_RJ 20104206.pdf]. Acesso em: 17.05.2016.

${ }^{69}$ Processo Administrativo Sancionador CVM 24/2005. Diretor-Relator: Sergio Weguelin. Presidente da sessão de julgamento: Maria Helena dos Santos Fernandes de Santana. j. 07.10.2008. Disponível em: [http://www.cvm.gov.br/sancionadores/sancionador/2008/20081007_2405.html]. Acesso em: 17.05.2016.
} 
Foram abordadas no caso discussões sobre a interpretação do artigo 13 da Instrução CVM no 358/02 e o poder regulamentar da CVM. Além disso, como se verá do estudo a seguir, foram feitas comparações com o julgamento de casos de insider nos Estados Unidos sobre indícios e presunções.

De acordo com a apuração da Comissão de Inquérito, os acusados teriam adquirido, ou possibilitado que terceiros adquirissem, ações da companhia em posse de informações privilegiadas sobre a negociação de alienação de controle da companhia e fechamento de seu capital então em curso.

Refazendo a cronologia utilizada pela Comissão de Inquérito para formular a acusação temos que a divulgação do fato relevante comunicando a existência de negociações para a alienação de ações entre os controladores da Bahema e a Marcosa ocorreu no dia 30.09.2002.

Somente três meses após a divulgação de tal fato, em 31.12.2002 é que foi firmado o Instrumento Particular de Promessa de Compra e Venda de ações, condicionando o fechamento do negócio à aprovação da Cartepillar. Apenas após sua aprovação, em 28.01.2003, foi comunicado ao mercado novo fato relevante informando os detalhes da operação e a intenção de realização de uma OPA para adquirir as ações remanescentes no mercado.

Diante desse cenário, os controladores da Bahema foram acusados de negociarem com valores mobiliários da companhia entre os meses de agosto de 2001 e julho de 2002.

Em suas defesas os investigados alegaram que a acusação teria se baseado em indícios frágeis, suposições sem qualquer suporte probatório, além do volume negociado não ter sido considerado expressivo em relação a quantidade 
de ações que já possuíam. Segundo a defesa, no período levantado pela acusação não teria existido fato relevante.

No entanto, o Diretor Sergio Weguelin, relator do processo em análise entendeu em seu voto que não haveria nenhum problema quanto ao conjunto de provas utilizado pela acusação, apesar de reconhecer que sua suficiência dependia de um juízo subjetivo do julgador.

\begin{abstract}
"A esse respeito, lembro, desde logo, que a lei não exige que o convencimento do julgador esteja amparado por uma demonstração absoluta e inquestionável dos fatos, com provas apontando univocamente na mesma direção. Ao contrário, vigora no Brasil o principio do livre convencimento motivado, segundo o qual o juiz pode apreciar livremente os elementos probatórios do processo, devendo, no entanto, fundamentar a formação de seu convencimento.

É possível, portanto, que haja provas contraditórias entre si, sem que isto impeça o julgador de formar sua conviç̧ão em um ou outro sentido, a depender do valor que atribua a cada uma destas provas. $\mathrm{E}$ ao falar em provas também me refiro às provas indiretas, isto é aos elementos que por si só sejam conhecidos e irrelevantes, mas que em conjunto autorizem a presunção quanto a fatos desconhecidos e relevantes.

Isso é importante porque em se tratando de 'insider trading', em que via de regra é necessário demonstrar que o agente detinha conhecimento da informação relevante, a prova definitiva e irrefutável do ilícito será praticamente impossível, exceto na hipótese de confissão por parte do acusado.

Evidentemente, não se quer com isso negar a importância de um suporte probatório adequado das imputações, nem deixar de reconhecer que, diante de uma dúvida razoável sobre os fatos, impõe-se a absolvição dos defendentes. Aqui se está apenas a lembrar que a fronteira entre os fatos comprovados e as meras especulações não é demarcada de forma objetiva, mas sim pela análise, subjetiva porém fundamentada, do julgador." 70
\end{abstract}

Ainda, de acordo com as defesas dos indiciados, a realização da operação, nesta altura, era algo incerto, isso porque ainda havia outras opções para resolução dos problemas financeiros enfrentados pela Bahema, desse modo não havia fato relevante a ser publicado.

\footnotetext{
${ }^{70}$ Extrato da Sessão de julgamento do Processo Administrativo Sancionador CVM 24/2005. DiretorRelator: Sergio Weguelin. Presidente da sessão de julgamento: Maria Helena dos Santos Fernandes de Santana. j. 07.10.2008. Disponível em: [http://www.cvm.gov.br/sancionadores/sancionador/2008/20081007_2405.html]. Acesso em: 17.05.2016
} 
O ex-Diretor da CVM, Marcos Pinto, em seu voto vencedor, explicou seu entendimento sobre a partir de que momento pode-se considerar a existência de um fato relevante.

\begin{abstract}
"Pois bem: a mim parece óbvio que o recebimento de uma oferta de compra de controle, ainda que não firme; e a existência de tratativas, ainda que intermitentes, são sim fatos capazes de influenciar a cotação das ações da companhia.

Em vista, disso, parecem-me irrelevantes as afirmações da defesa de que o preço da venda ainda não estava definido e de que ainda pairavam dúvidas quanto à concretização da operação.

No nosso regime jurídico, só uma pergunta deve ser feita: A informação de que dispõe o administrador ou controlador pode "influir de modo ponderável na cotação dos valores mobiliários"? Se a resposta for afirmativa, há fato relevante.

(...)

Mas daí a afirmar que, nessa situação, o controlador ou administrador também pode negociar com as ações, de posse de uma informação que, mesmo incerta, o coloca em posição de vantagem em relação aos demais acionistas - isso não me parece de modo algum aceitável." 71
\end{abstract}

Apesar de entender que tais informações configurariam fatos relevantes, o ex-Diretor se manifestou no sentido de absolver dois dos três membros da família que controlava a Companhia por considerar que as negociações realizadas não tiveram o intuito de obter vantagem para si ou para terceiros, requisito que, como visto nesse estudo, é essencial para configuração do ilícito.

Quanto ao terceiro membro, Sr. Carlos Affonso Ferreira, votou no sentido de que a prática do insider, de fato, teria ocorrido. Isto porque, diferentemente de seus irmãos, Sr. Carlos não só adquiriu um maior volume de ações como concretizou muitas delas já na vigência da Instrução CVM 358/02, que, de

\footnotetext{
${ }^{71}$ Extrato da Sessão de julgamento do Processo Administrativo Sancionador CVM 24/2005. DiretorRelator: Sergio Weguelin. Presidente da sessão de julgamento: Maria Helena dos Santos Fernandes de Santana. j. 07.10.2008. Disponível em: [http://www.cvm.gov.br/sancionadores/sancionador/2008/20081007_2405.html]. Acesso em: 17.05.2016
} 
acordo com o entendimento do Diretor, teria tornado a intenção de obter vantagem irrelevante para caracterização do ilícito.

No tocante às acusações de prática de insider de mercado e quebra do dever de sigilo feitas aos conselheiros da Bahema S.A., a defesa alegou que por não serem administradores da companhia, os acusados não possuíam com esta qualquer dever fiduciário a ser observado.

O ex-Diretor Marcos Pinto, em seu voto, considerou que apesar dos acusados serem terceiros em relação à Bahema, por serem conselheiros da Bahema S.A. que possuía participação indireta na Companhia, possuíam sim um dever fiduciário de guardar sigilo para com a Bahema S.A., visto que a cotação de seus valores mobiliários seriam indiretamente afetadas pela alienação de controle da Bahema.

"Portanto, terceiros não podem, e nunca puderam, ser condenados por quebra de dever de sigilo, pois esse dever não lhes é imposto por qualquer lei ou regulamento.

Ocorre que Luiz Carlos Pires de Araújo e Luiz Alves Paes de Barros eram terceiros apenas em relação à Bahema Equipamentos, mas não em relação à Bahema. Portanto, eles também eram administradores de uma companhia aberta. $E$ uma companhia aberta que seria indiretamente afetada pela alienação do controle da Bahema Equipamentos.

(...)

Portanto, a alienação do controle da Bahema Equipamentos era capaz de afetar, indiretamente, a cotação dos valores mobiliários da Bahema.

Por esse motivo, entendo que Luiz Carlos Pires de Araújo e Luiz Alves Paes de Barros violaram seu dever de sigilo, em infração aos dispositivos legais citados acima." ${ }^{72}$

\footnotetext{
${ }^{72}$ Extrato da Sessão de julgamento do Processo Administrativo Sancionador CVM 24/2005. DiretorRelator: Sergio Weguelin. Presidente da sessão de julgamento: Maria Helena dos Santos Fernandes de Santana. j. 07.10.2008. Disponível em: [http://www.cvm.gov.br/sancionadores/sancionador/2008/20081007_2405.html]. Acesso em: 17.05.2016
} 
Mais adiante, passamos a tratar das imputações feitas ao Sr. Daniel Birmann acusado de insider de mercado por ter negociado, por meio de terceiros, valores mobiliários da Companhia.

De acordo com as investigações feitas pela Comissão de Inquérito, o acusado, auxiliado pelo então sócio majoritário da companhia Calmaria, utilizava a companhia como "laranja" para negociar ações da Bahema, com o objetivo de camuflar as operações escondendo o beneficiário final.

A decisão foi inovadora nesse sentido. Bem se sabe que para a condenação de um insider de mercado deve haver prova de seu acesso à informação. O Relator, no entanto, entendeu que tal prova poderia ser extraída das características da operação e da existência de um mecanismo fraudulento visando esconder o beneficiário final. Para o Relator, a simples existência de tal mecanismo é prova de que houve acesso à informação privilegiada ainda não divulgada ao mercado.

\footnotetext{
"Seguindo essa tendência - ou seja, presumir que houve acesso a informações necessárias à prática do ato ilícito com base em operações improváveis no mercado de valores mobiliários - há também os Processos Administrativos CVM 2002/5015, 04/01 e 2004/210(14).

O entendimento que prevaleceu nestes casos, a meu juízo, reflete a percepção de que não é necessário demonstrar toda a dinâmica dos fatos irregulares, desde que se possa assegurar sua ocorrência.

Portanto, tendo em vista os padrões de operação dos defendentes e o uso de subterfúgios para efetuá-las, pode-se concluir que Daniel Birmann obteve antecipadamente acesso à informação da venda do controle da Bahema Equipamentos e utilizou tal informação indevidamente em proveito próprio. Para tanto, contou com a colaboração consciente de Edivan Pinheiro Viegas e da Calmaria.

Observo, porém, que a Calmaria não deve ser penalizada por tais operações, haja vista que foi mero instrumento utilizado em benefício de Daniel Birmann e Edivan Pinheiro Viegas, aos quais cumpre arcar integralmente com o ônus do ato ilícito."
}

O caráter inovador dessa interpretação está no entendimento de que operações realizadas em condições suspeitas podem ser consideradas provas de 
acesso à informação, visto que sempre se preocupou muito em se buscar o meio de acesso à informação.

Apesar disso, no caso em questão a utilização da Calmaria como "laranja" foi argumento suficiente para a condenação do acusado por negociação em posse de informações privilegiadas.

\subsection{Caso Sadia/Perdigão - PAS n SP 2007/0117}

Outro caso bastante interessante é o Processo Administrativo Sancionador $\mathrm{n}^{\circ}$ SP 2007/0117 73 instaurado para apurar o eventual uso indevido de informações relevantes ainda não divulgadas ao mercado na negociação de valores mobiliários de emissão da Perdigão na Bolsa de Nova York, conduta supostamente vedada pelo art. $155 \S 1^{\circ}$ da Lei das S/A.

O administrador da Sadia à época, Sr. Romano Ancelmo Fontana, foi acusado pela prática de insider. A CVM decidiu pela condenação a pena de inabilitação temporária pelo prazo de cinco anos para o exercício do cargo de administrador ou conselheiro fiscal de companhia aberta por ter negociado American Depositary Receipts (ADR's) da Perdigão na Bolsa de Nova Iorque (NYSE), antes da divulgação do fato relevante ${ }^{74}$ de compra da Perdigão pela Sadia.

\footnotetext{
73 Processo Administrativo Sancionador CVM SP 2007/0117. Diretor-Relator: Eli Loria. Presidente da sessão de julgamento: Maria Helena dos Santos Fernandes de Santana. j. 26.02.2008. Disponível em: [http://www.cvm.gov.br/sancionadores/sancionador/2008/20080226_SP20070117.html]. Acesso em: 16.05.2016.

${ }^{74}$ Sob a alegação de uso de informação privilegiada na mesma operação, a SEC fechou acordo com Luiz Antonio Murat Junior, ex-diretor financeiro e de relações com investidores da Sadia, e com Alexandre Ponzio de Azevedo, ex-funcionário do ABN Amro Real. Sem admitir nem negar culpa, eles aceitaram pagar multas no valor de US\$ 364.000 e US\$ 135.000, respectivamente. Além disso, o primeiro não poderá atuar como executivo de empresas de capital aberto por cinco anos, enquanto que o segundo ficará fora do mercado financeiro por três anos. Sobre o caso, ver reportagem publicada na Revista
} 
De acordo com a acusação entre os dias 05 e 12.07.2006, antes da divulgação pela Sadia de oferta pública de aquisição de 50\% mais uma ações de emissão da Perdigão, que só veio a ocorrer em 16.07.2006, o Sr. Romano adquiriu 18.000 ADR's representativos de ações de emissão da Perdigão (correspondentes a 36.000 ações ordinárias), e se desfez dessa posição em 21.07.2006, antes da divulgação pública da revogação da oferta pela Sadia, tendo assim auferido um ganho de US\$139,114.50.

Apesar de a negociação ter ocorrido na Bolsa de Nova Iorque, a CVM se entendeu competente para julgar o caso pautando-se no disposto no $\S 6^{\circ}$ do art. $9^{\circ}$ da Lei $6.385 / 76^{75}$.

A defesa, por sua vez, alegou que a Autarquia teria competência para apreciar a matéria, visto que não teria havido nenhum dano a pessoas residentes no Brasil, e ainda, que não teriam ocorrido fatos relevantes em território nacional. Dessa forma, como a conduta do acusado já havia sido processada e penalizada pelas autoridades norte-americanas, não poderia existir uma nova condenação por um mesmo fato, sob pena de infração ao princípio de vedação do bis in idem.

$\mathrm{Na}$ justiça norte-americana o $\mathrm{Sr}$. Romano foi (i) proibido permanentemente de violações a determinadas disposições da legislação norteamericana; (ii) obrigado a pagar US\$ 142,848.95, equivalente à quantia

\footnotetext{
Exame: "Os infiltrados. A punição dos executivos da Sadia e do ABN por insider trading deve ser apenas o primeiro caso de uma serie." Edição de 09.03.2007. Disponível em [http://exame.abril.com.br/revistaexame/edicoes/888/noticias/os-infiltrados-m0123965]. Acesso em 16.05.2016.

${ }^{75}$ Art $9^{\circ}, \S^{\circ}$ da Lei 6.385/76: A Comissão será competente para apurar e punir condutas fraudulentas no mercado de valores mobiliários sempre que:

I - seus efeitos ocasionem danos a pessoas residentes no território nacional, independentemente do local em que tenham ocorrido; e

II - os atos ou omissões relevantes tenham sido praticados em território nacional.
} 
supostamente ganha de forma indevida; (iii) obrigado a pagar uma penalidade civil de 1,25 vezes o valor supostamente ganho de forma indevida, correspondente a US\$173,893.13; e (iv) inabilitado a exercer o cargo de administrador de companhia aberta pelo prazo de 5 anos. O acusado ainda assinou um termo de compromisso com a SEC.

Apesar dos esforços da defesa em descaracterizar a competência da CVM para apreciação do Processo, o Diretor-Relator Eli Loria entendeu de forma diversa:

"Com relação ao argumento da Defesa de vedação de duplo apenamento, entendo que a Constituição Federal de 1988 implicitamente acolhe tal princípio, ainda que não de forma absoluta, em decorrência dos princípios da legalidade, ampla defesa e devido processo legal. Para que se reconheça a incidência de "bis in idem" é necessário que as situações sob análise sejam similares.

No caso, o compromisso assinado pelo acusado, citado pela Defesa, deu-se em outra jurisdição, sendo diverso o valor tutelado. A regra geral pátria privilegia a independência das instâncias e, portanto, 0 apenamento do acusado por esta CVM não agride o princípio do 'non bis in iden'. Outrossim, o próprio termo de compromisso assinado pelo acusado nos Estados Unidos prevê a continuidade das investigações por parte da CVM, afirmando citado documento que "A investigação da Comissão sobre este assunto prossegue.' (fls. 257)",76

Após a análise do trecho do voto, pode-se entender que o Diretor-Relator ressaltou a clareza do art. $9^{\circ}, \S 6^{\circ}$ da Lei $6.385 / 76$ quanto à legitimidade da CVM para apuração da conduta em questão.

Complementando o voto de Eli Loria, o Diretor Marco Barbosa Pinto, faz uma analogia ao âmbito civil, no qual a competência do Poder Judiciário

\footnotetext{
${ }^{76}$ Extrato da sessão de julgamento do Processo Administrativo Sancionador CVM SP 2007/0117. Diretor-Relator: Eli Loria. Presidente da sessão de julgamento: Maria Helena dos Santos Fernandes de Santana. j. 26.02.2008. Disponível em: [http://www.cvm.gov.br/sancionadores/sancionador/2008/20080226_SP20070117.html]. Acesso em: 16.05.2016.
} 
brasileiro é definida pelo art. 21 do Novo $\mathrm{CPC}^{77}$. Dessa forma, visto que o acusado é residente e domiciliado no Brasil, como consta a ata de Assembleia que o elegeu como membro do Conselho de Administração, restaria demonstrada a competência da CVM para julgamento do caso, se o CPC fosse aplicável.

Continuando a análise do caso, cabe lembrar que, conforme visto anteriormente, o Sr. Alexandre Ponzio, na qualidade de Superintendente Executivo de Empréstimo Estruturado e Gestão de Portifólio de Crédito do Banco ABN AMRO Real S.A, também foi acusado de utilizar informação relevante ainda não divulgada ao mercado com o intuito de auferir vantagem em operações de compra de ADR's da Perdigão antes da divulgação do fato relevante.

No entanto, as acusações impostas ao Sr. Alexandre não chegaram a julgamento, isto porque o mesmo assinou um termo de compromisso ${ }^{78} \mathrm{com}$ a Autarquia no qual se comprometeu a pagar o valor de $\mathrm{R} \$ 238.000,00$ e ainda, informar que foi demitido por justa causa do banco ABN AMRO Real S.A.

Posteriormente, o caso ganhou um grande destaque visto que o Ministério Publico Federal (MPF) pediu a abertura de ação penal contra o Sr. Romano Ancelmo Fontana Filho, o Sr. Luiz Gonzaga Murat Júnior, ex-diretor de

\footnotetext{
${ }^{77}$ Apesar de no texto original do voto constar referência ao art. 88 do CPC que não está mais em vigor no ordenamento jurídico brasileiro, aqui transcrevo o art. 21 do NCPC que corresponde ao artigo da antiga lei.

Art. 21. Compete à autoridade judiciária brasileira processar e julgar as ações em que: I - o réu, qualquer que seja a sua nacionalidade, estiver domiciliado no Brasil;

II - no Brasil tiver de ser cumprida a obrigação;

III- o fundamento seja fato ocorrido ou ato praticado no Brasil.

Parágrafo único. Para o fim do disposto no inciso I, considera-se domiciliada no Brasil a pessoa jurídica estrageira que nele tiver agência, filial ou sucursal.

${ }^{78}$ Decisão do colegiado sobre apreciação de proposta de termo de compromisso - PAS SP2007/0119 Alexandre Ponzio De Azevedo o PAS SP 2007/0119, realizado em 04.03.2008. Disponível em [http://www.cvm.gov.br/export/sites/cvm/decisoes/anexos/0004/5912-0.pdf]. Acesso em 16.05.2016.
} 
Finanças e Relações com os Investidores da Sadia e o Sr. Alexandre Ponzio de Azevedo, pela prática do insider trading.

De acordo com o próprio MPF, esta foi a primeira denúncia oferecida no país tendo como objetivo a condenação dos executivos pela prática do insider trading.

\subsection{Caso Eletropaulo - PAS 04/04}

O processo foi instaurado para apurar o eventual uso de informação privilegiada relacionada ao processo de reestruturação das dívidas do Grupo AES junto ao BNDES com a negociação de ações preferenciais da Eletropaulo, em suposta infração ao parágrafo $4^{\circ}$ do art. 155 da Lei das S/A e do parágrafo $1^{\circ}$ art. 13 da Instrução CVM 358/0279.

Foram acusados por insider Carlos Augusto Coelho Branco, na qualidade de advogado do escritório contratado por BNDES e BNDESPAR, e Roberto Mário Amaral Lima Neto, na qualidade de advogado do escritório contratado pelo Grupo AES.

O caso traz discussões como insider primário vs. insider secundário, a interpretação do art. 13 da Instrução CVM nº 358/02, no que diz respeito ao requisito subjetivo do insider trading, como visto no decorrer do presente estudo, finalidade de obter vantagem.

\footnotetext{
${ }^{79}$ Processo Administrativo Sancionador CVM 04/2004. Diretor-Relator e Presidente da sessão de julgamento: Marcelo Fernandez Trindade. j. 28.06.2006. Disponível em: [http://www.cvm.gov.br/sancionadores/sancionador/2006/20060628_0404.html]. Acesso em: 17.05.2016.
} 
O processo se originou da privatização da Eletropaulo Metropolitana Eletricidade de São Paulo S.A. (“Eletropaulo”), objetivando a apuração de eventual uso de informação privilegiada pelos advogados que estiveram envolvidos em trabalhos temporários relacionados ao processo de reestruturação das dívidas do Grupo AES junto ao Banco de Desenvolvimento Econômico Social ("BNDES").

No período anterior à divulgação do fato relevante pelo Grupo AES, a CVM detectou movimentações atípicas nas cotações e no volume de negociação das ações preferenciais de emissão da Eletropaulo, e após algumas investigações realizadas pela Comissão de Inquérito, entendeu-se que haveria a possibilidade de ter ocorrido um vazamento do teor do Memorando de Entendimentos, que até a sua divulgação ao mercado era sigiloso e de cunho relevante.

Diante dessa situação, constatou-se que os advogados penalizados teriam negociado com ações de emissão da Eletropaulo, adquirindo-as após o início do processo de renegociação, e as alienando após o encerramento desse processo.

Os indiciados negaram qualquer relação de influência entre a compra das ações e suas participações na operação, alegando inclusive que na fase em que se encontrava o caso não havia qualquer possibilidade de acordo. Sr. Carlos ainda acrescentou que era investidor do mercado de ações e que, inclusive, já havia adquirido ações da Eletropaulo anteriormente.

No decorrer da análise dos elementos legais e regulamentares para a configuração do ilícito, o Relator se baseando no $\S 4^{\circ}$ do art. 155 , apresentou dois requisitos para sua caracterização o (i) elemento volitivo, traduzido na finalidade de auferir vantagem; e (ii) informação relevante e sigilosa. Diferencia-se a norma legal da norma regulamentar pela existência do requisito da finalidade de 
auferir vantagem, isso porque, como foi visto, tal requisito não está explícito na norma regulamentar, havendo apenas uma presunção de que o insider e o terceiro a ele equiparado, atuam com a finalidade de obter lucro.

Neste sentido, o Relator relembra o voto do então Diretor Nelson Eizirik no processo IA $02 / 85$, que disciplinou que não incide qualquer presunção ao insider de mercado, cabendo à Autarquia provar o acesso à informação relevante. Tal presunção, somente seria cabível nos casos de insider primário, em que há atuação de administradores da companhia negociando ações no mercado ao mesmo tempo em que podem ter acesso a informações de cunho relevante sobre os negócios da companhia emissora.

Dessa forma, os referidos advogados foram equiparados pelo Colegiado da CVM, a insiders primários pelo fato de terem, ainda que temporariamente, participado dos negócios das companhias envolvidas na reestruturação e, por tal motivo, terem tido total acesso às informações sigilosas e relevantes da companhia.

Pode-se compreender isso da leitura do trecho do voto do Relator, abaixo transcrito.

\footnotetext{
"Tradicionalmente se faz a distinção entre o insider primário, administrador da companhia ou terceiro com acesso direto às informações da companhia, sobre os quais recai a presunção iuris tantum de que detinham a informação, e o terceiro que negocia de posse da informação privilegiada mas não é insider, e em relação ao qual é preciso provar o conhecimento dos fatos não relevados ao mercado.

Sob esse prisma, contudo, tal discussão é irrelevante neste caso, pois ficou comprovado de maneira incontroversa neste processo que os referidos advogados participaram ativamente das negociações e da elaboração de documentos relativos ao ajuste que veio a ser celebrado entre credor e devedor, e tiveram, portanto, acesso à informação relativa a tais eventos antes do mercado." 80
}

\footnotetext{
${ }^{80}$ Processo Administrativo Sancionador CVM 04/2004. Diretor-Relator e Presidente da sessão de julgamento: Marcelo Fernandez Trindade. j. 28.06.2006. Disponível em:
} 
Em seguida foi feita uma análise detalhada da conduta individual de cada um dos acusados, a fim de efetivamente provar a ilicitude de seus atos com base nos artigos mencionados.

Um dos acusados argumentou em sua defesa que não teria sido o responsável por dar a ordem de negociação, a qual teria sido realizada por um agente autônomo de sua corretora, com base em uma autorização para negociar pequenas quantias de maneira discricionária. Além disso, o acusado teria comprado ações anteriormente à divulgação de fato relevante e as alienado no dia imediatamente seguinte a compra, auferindo o lucro ínfimo de $\mathrm{R} \$ 84,00$.

Diante disso, o Relator entendeu que não houve, por parte do acusado, a finalidade de auferir vantagem ao adquirir as ações, não restando comprovado o elemento subjetivo do $\S 4^{\circ}$ do art. 155 da Lei das S/A.

Ainda em seu voto, o Relator afasta a aplicação do art.13 $\S 1^{\circ}$ da Instrução CVM no 358/02, alegando o seguinte:

"Por isto, entendendo que ficou demonstrado pela prova dos autos que a aquisição de ações pelo indiciado não teve por finalidade o auferimento de vantagens, e que, portanto, não ficou comprovado o elemento subjetivo do tipo do art. $155, \S 4^{\circ}$, da Lei 6.404/76, considero que o indiciado deva ser absolvido da imputação de violação dessa norma. Do mesmo modo, por entender que a presunção de atuação com finalidade de lucro, do art. $13, \S 1^{\circ}$, da Instrução $358 / 02$, restou revertida pela prova produzida pelo indiciado, no sentido de que havia conferido poderes discricionários para que o agente autônomo da Corretora Fair atuasse dando ordens em seu nome, até um certo valor, e de que reverteu a ordem indevida tão logo dela teve notícia, mesmo com prejuízo líquido, voto pela absolvição do indiciado também quanto a essa segunda imputação."

\footnotetext{
[http://www.cvm.gov.br/sancionadores/sancionador/2006/20060628_0404.html]. Acesso_em:
} 17.05.2016. 
Dessa forma, foi absolvido de todas as acusações de prática de insider trading.

Já com relação ao outro acusado, a situação é um pouco diferente. Isto porque, o indiciado teria negociado e participado ativamente do acordo, e nesse cenário teria negociado com as ações da companhia antes da divulgação do fato relevante, tendo ainda vendido as ações obtendo ganho expressivo.

Em sua defesa alega que não teria havido fato relevante não divulgado, na medida em que as negociações passavam por altos e baixos, com a possibilidade de ajuizamento de ações e encerramento da possibilidade de acordo.

Apesar disso, o Relator entendeu que o acusado teria realizado o chamado short swing, adquirindo e alienando ações da companhia em um curto período de tempo. Tal fato, combinado com o expressivo lucro auferido impedem que a presunção seja afastada, como se depreende do trecho abaixo.

"Quanto à finalidade de obtenção de vantagem através da utilização das informações relevantes de que estava ciente, o indiciado não logrou, a meu ver, afastar a presunção regulamentar do art. $13, \S 1^{\circ}$, da Instrução 358/02. A alienação das ações, pouco tempo depois da divulgação do sucesso da renegociação, com expressivo lucro, impede, a meu ver, que se afaste a presunção de que, ao negociar com a informação sobre os detalhes da renegociação da dívida, não divulgados ao mercado, o acusado valeu-se dessa informação, com a finalidade de auferir lucro, que aliás alcançou."

Dessa forma se entende que, o acusado se aproveitou de sua situação privilegiada em relação aos demais investidores e que operou com objetivo de auferir lucro e por essas razões foi condenado ao pagamento de multa pecuniária. 


\section{Conclusão}

Discutiu-se, no presente trabalho, questões sobre o uso de informação privilegiada no âmbito do mercado de valores mobiliários, analisando e identificando os agentes responsáveis por essa conduta.

Diante disso, observa-se que são extremamente necessárias a repressão e prevenção à prática do insider trading em um mercado de valores mobiliários que preza pela segurança e confiabilidade dos investidores e dos investimentos.

Feita uma breve análise da evolução legislativa brasileira sobre o tema, se pode observar que a informação tem papel de máxima importância, seja no desenvolvimento de tecnologias, na vida cotidiana e principalmente, para fins deste trabalho, no âmbito do mercado brasileiro, tendo em vista que a transparência e a confiança no mercado são essenciais para seu desenvolvimento.

Diante disso, o ordenamento jurídico transformou a prestação de informações em dever a ser cumprido por aqueles que administram as companhias abertas com o objetivo de impedir a prática do insider trading. Para isso, foi utilizado como base o princípio do full disclosure que, como visto, consiste no dever de divulgar informações da companhia de forma clara e transparente, auxiliando os participantes do mercado na análise de seu eventual investimento na companhia.

Atualmente entende-se que devem ser expurgados do mercado os maus profissionais - aqueles que praticam o insider trading - visto que suas atitudes 
põem em risco a saúde do mercado de valores mobiliários e da própria companhia para a qual trabalham. De fato, são eles os responsáveis por transmitir informações relevantes aos investidores e, se sua conduta se pauta na mesma utilização desonesta dessas informações mediante o aproveitamento de uma posição privilegiada frente aos demais investidores, com o fim de lograr uma vantagem ilícita, não há como mantê-los em suas respectivas funções.

Após a análise da situação do mercado e sua regulamentação sobre a divulgação de informações relevantes, demonstrou-se como a doutrina e a CVM têm distinguido os diferentes tipos de agentes na prática do insider, com o objetivo de reprimir o uso de informações privilegiadas para obter vantagens indevidas em negociações com valores mobiliários.

A partir disso, a distinção é feita entre os insiders primários e secundários. Tal distinção é de suma importância para análise do ilícito.

Os insiders primários são os agentes que possuem deveres de ética e lealdade perante a companhia devido à função que nela exercem. Dessa forma, tem-se entendido que para eles recai uma presunção iuris tantum de que possuíam acesso a informação ainda não divulgada. Os insiders secundários, por sua vez, são terceiros que não possuem vínculo profissional com a companhia, aqueles que obtêm conhecimento da informação privilegiada por intermédio da administração, por exemplo, por isso tal presunção não existe. Portanto, o conhecimento e a utilização da informação privilegiada para auferir vantagem indevida, nesses casos, deve ser provada de forma inequívoca por aqueles que acusam.

Neste contexto, pode-se perceber que uma das principais diferenças entre os tipos de insider está no ônus da prova. Essa conclusão se extrai no caso do 
insider primário, por exercer cargo que lhe possibilita o acesso irrestrito às decisões e às negociações da companhia. Portanto, o ônus da prova é do agente, sendo ele o responsável por provar sua inocência. Quanto ao insider secundário, é ônus do regulador comprovar a prática do ilícito.

Além disso, é importante a proteção da figura do investidor, uma vez que os seus investimentos contribuem para a formação de capital, estimulando o desenvolvimento econômico do país.

Para tanto, como visto, se faz necessário que as companhias tenham uma política forte de divulgação informacional, bem como uma política de negociação interna, para seus funcionários, de forma a proteger-se melhor contra o uso de informações relevantes. Destacando o respeito ao dever de informar e o princípio do full disclosure.

Neste sentido, pela análise dos julgados da CVM feita nesse trabalho, percebe-se um combate rigoroso à prática do insider e a fiscalização das empresas no tocante a uma divulgação efetiva de informações relevantes ao mercado, bem como uma, cada vez maior, atenção da CVM às movimentações atípicas nos valores mobiliários de emissão das companhias que possam indicar a utilização indevida de informações ainda não disponíveis.

O próximo passo, na nossa opinião, é tornar ainda mais efetivas as sanções a esses ilícitos. 


\section{Referências Bibliográficas}

- Doutrina:

ARANHA, Adalberto José Q. T. de Camargo. Da prova no processo penal. $7^{\circ}$ Ed. São Paulo: Saraiva, 2006.p.84

BARBOSA, Marcelo; BARROS, Octavio Fragata; BRICK, Bruna Zoghbi; CAMPINHO, Bernardo Capela. Direito societário e mercado de capitais. Rio de Janeiro: Editora FGV, 2009. Vol. 2, t. 2, p. 78.

BLOK, Marcella. "Insider Trading: o descumprimento do dever de lealdade pelo uso de informações privilegiadas". Revista de Direito Bancário e do Mercado de Capitais, ano 15, n. 55, São Paulo: Revista dos Tribunais, jan/mar. 2012. pp. 83-129.

CAMPOS, Luiz Antonio de Sampaio. Deveres e responsabilidades,. In: LAMY Filho, Alfredo; Pedreira, José Luiz Bulhoes (coord.). Direito das Companhias. Rio de Janeiro: Forense, 2009. p. 1.151 v. 1.

CARVAlHOSA, Modesto. Comentários à lei de Sociedades Anônimas, Lei 6.404, de 15 de dezembro de 1976, com as modificações das Leis n. 9.457, de 5 de maio de 1997, 10.303, de 31 de outubro de 2001, e 11.638, de 28 de dezembro de 2007, 4. ed. rev. e atual. São Paulo: Saraiva, 2009, p.315.

CARVAlHOSA, Modesto; EIZIRIK, Nelson. A nova Lei das S/A., São Paulo: Saraiva, 2002. pp. 322-323. 
CARVAlHOSA, Modesto. Comentários à Lei de Sociedades Anônimas, $3^{\circ}$ volume: artigos 138 a 205 - 5 ed. rev. e atual. São Paulo: Saraiva, 2011. p.415 e 416.

CASTELLAR, João Carlos. Insider Trading e os Novos Crimes Corporativos. Rio de Janeiro: Ed. Lumen Juris, 2008. p. 141.

CASTRO, Hélio de Oliveira Portocarrero; e EIZIRIK, Nelson. Regulação e Controle do Mercado de Capitais (o papel da SEC ma experiência norteamericana). Rio de Janeiro, IBMEC, 1974. p. 100.

COELHO, Walter. Prova Indiciária em Matéria Criminal. Porto Alegre: Sérgio Antônio Fabris, 1996, pp. 59 - 532.

COMPARATO, Fábio Konder. Direito Público - Estudos e Pareceres, São Paulo: Saraiva, 1996, pp. 256 e 257

COMPARATO, Fábio Konder. A regra de sigilo nas ofertas públicas de aquisição de ações. In: Direito Empresarial: Estudo e Pareceres. Rio de Janeiro: Saraiva, 1990. pp. 331-353.

COMPARATO, Fábio Konder. "Insider Trading: sugestões pra uma moralização do nosso mercado de capitais." Revista de Direito Mercantil, Industrial, Econômico e Financeiro. São Paulo, nº 2, ano X, jan./mar. 1971, pp. 41-51.

COMPARATO, Fábio Konder. O poder de controle na sociedade anônima. $2^{\mathrm{a}}$ ed. atual. São Paulo: Ed. Revista dos Tribunais, 1977, p. 223. 
CORREA LIMA, Osmar Brina. Responsabilidade civil dos administradores de sociedades anônimas. Rio de Janeiro: Aide, 1989, p. 75

DIAS, Amanda Tayar Duarte. "Questões atuais envolvendo o Insider Trading”. Revista de Direito Bancário e do Mercado de Capitais; ano 12, n. 45, São Paulo: Revista dos Tribunais, jul./set. 2009. p. 128.

EIZIRIK, Nelson, GAAL, Ariádna B., PARENTE Flávia e HENRIQUES, Marcus de Freitas. Mercado de Capitais - Regime Jurídico, 3.ed. revista e ampliada. - Rio de Janeiro: Renovar, 2011, p. 564

EIZIRIK, Nelson. A Lei das S/A Comentada. Volume III - $2^{\mathrm{a}}$ ed. rev. e ampliada - artigos 138 a 205. São Paulo: Quartier Latin, 2015

EIZIRIK, Nelson. “A instrução CM 31/84 e a Regulamentação do 'Insider Trading" ". Revista de Direito Mercantil, Industrial, Econômico e Financeiro. São Paulo: nº55, ano XXIII, jul./set., pp. 170-176.

EIZIRIK, Nelson. "Insider Trading e a Responsabilidade de Administrador de Companhia Aberta." Revista de Direito Mercantil, Industrial, Econômico e Financeiro. São Paulo: no 50, ano XXII, abr./jun. 1983. pp. 42 - 57

EMERSON, Robert W. e HARDWICKE, John W. Business Law, $3^{\mathrm{a}}$ ed., Barron's Educational Series Inc., 1997, EUA, p. 366.

FILHO, Alfredo Lamy; PEDREIRA, José Luiz Bulhões. A lei das S.A. $3^{\mathrm{a}}$ Ed. Rio de Janeiro: Renovar, 1997. Vol. 1 p. 508. 
FILHO, Alfredo Lamy; PEDREIRA, José Luiz Bulhões. Direito das Companhias. Vol.1 Rio de Janeiro: Forense, 2009 p. 1128.

FRAGOSO, Heleno Cláudio. Jurisprudência Criminal, vol. 2, Forense pp. 446 $-532$

GUEDES, Demian. Processo administrativo e democracia: uma reavaliação da presunção de veracidade. Belo Horizonte; Fórum, 2007. p. 125.

IOSCO, Internacional Organization of Securities Comissions. Insider Trading. How Jurisdictions Regulate It. March/2003. Disponível em: [https://www.iosco.org/library/pubdocs/pdf/IOSCOPD145.pdf]. Acesso em 16.05.2016.

MACIEL, Karina Teresa da Silva; MARTIN, Antônio. "Efetividade da repressão ao insider trading”. Revista de Direito Empresarial, São Paulo, v. 3, maio 2014, p. 149.

MILLER, Daniel Schiavoni. et al. Governança Corporativa e Full Disclosure: O Direito à Informação Como Direito Subjetivo Instrumental, Implicitamente Essencial e Inderrogável do Acionista. In: CANTIDIANO, Luiz Leonardo. (org). Governança Corporativa: empresas transparentes na sociedade de capitais. Lazuli Editora, 2004, pp. 91-128.

MOYE, John E. The law of business organizations, $5^{\mathrm{a}}$ ed., EUA : International Thomsin Publishing Company, 1998, p. 259.

MÜSSNICH, Francisco Antunes Maciel. “A utilização desleal de informações privilegiadas - "Insider Trading" - no Brasil e nos Estados Unidos". Revista de 
Direito Mercantil, Industrial, Econômico e Financeiro. vol.34. São Paulo: Ed. RT, 1979, p. 35.

MÜSSNICH, Francisco Antunes Maciel. O Insider Trading no Direito Brasileiro. 2015. 148 f. Dissertação (Mestrado em Direito da Regulação) Fundação Getúlio Vargas - FVG. Rio de Janeiro, 2015.

LEÃES, Luiz Gastão Paes de Barros. "A adoção do Chinese Wall e a repressão ao insider trading." Revista de Direto Bancário e do Mercado de Capitais. vol. 47. São Paulo: Ed. RT, 2010. p. 227.

PARENTE, Norma Jonssen. Aspectos jurídicos do insider trading. CVM: 1978. Disponível em: [http://www.cvm.gov.br/export/sites/cvm/menu/acesso_informacao/serieshist/e studos/anexos/Aspectos-Juridicos-do-insider-trading-NJP.pdf]. Acesso em: 05.05.2016.

PINA, Carlos Costa. Dever de informação e responsabilidade pelo prospecto no mercado primário de valores mobiliários, Coimbra: Coimbra Editora, 1999, pp. $28,29$.

PRADO, Viviane Muller; VILELA, R. Radiografia de insider trading na CVM. 2014. (Relatório de pesquisa).

ROSSI, Lívia Trabulsi. "Fundamentos para a constituição de prova indiciária em casos de Insider Trading de Mercado". Revista de Direito Bancário e do Mercado de Capitais, ano 18, n. 69, São Paulo: Revista dos Tribunais, jul./set. 2015. pp. $123-148$ 
RUIZ, Daniel Entrena. El empleo de información privilegiada en el mercado de valores: un estudio de su régimen administrativo sancionador. España: Editorial Aranzadi, 2006, p. 273

RUY, Fernando Estevam Bravin. Direito do investidor consumidor no mercado de capitais e nos fundos de investimento. Rio de Janeiro: Lumen Juris, 2010. p.178.

TRINDADE, Marcelo Fernandez, Mútuo de ações e insider trading. In: CASTRO, Rodrigo Rocha Monteiro de. WARDE JÚNIOR, Walfrido Jorge; GUERREIRO, Ana Carolina Dias Tavares (coord.). Direito Empresarial e outros estudos em homenagem ao Professor Tavares Guerreiro, São Paulo: Quartier Latin, 2013, p. 527.

\section{- Jurisprudência:}

Extrato da sessão de julgamento do Processo Administrativo Sancionador CVM RJ 2010/4206. Diretor-Relator: Alexsandro Broedel Lopes. Presidente da sessão de julgamento: Maria Helena dos Santos Fernandes de Santana. j. 23.08.2011. Disponível em: [http://www.cvm.gov.br/sancionadores/sancionador/2011/20110823_RJ20104 206.html]. Acesso em: 04.05.2016.

Extrato da sessão de julgamento do Processo Administrativo Sancionador CVM 04/2004. Diretor-Relator e Presidente da sessão de julgamento: Marcelo Fernandez Trindade. j. 28.06.2006. Disponível em: [http://www.cvm.gov.br/sancionadores/sancionador/2006/20060628_0404.htm 1]. Acesso em: 05.05.2016. 
Extrato da sessão de julgamento do Processo Administrativo Sancionador CVM RJ 2011/3665. Diretora-Relatora: Luciana Dias. Presidente da sessão de julgamento: Maria Helena dos Santos Fernandes de Santana. j. 03.04.2012. Disponível em: [http://www.cvm.gov.br/sancionadores/sancionador/2012/20120403_RJ20113 665.html]. Acesso em: 05.05.2016.

Extrato da sessão de julgamento do Processo Administrativo Sancionador CVM SP2007/0117. Diretor-Relator: Eli Loria. Presidente da sessão de julgamento: Maria Helena dos Santos Fernandes de Santana. j. 26.02.2008. Disponível em: [http://www.cvm.gov.br/sancionadores/sancionador/2008/20080226_SP20070 117.html]. Acesso em: 09.05.2016.

Extrato da sessão de julgamento do Processo Administrativo Sancionador CVM 2007/1079. Voto do Diretor: Pedro Oliva Marcilio de Sousa. Diretor-Relator: Eli Loria Presidente da sessão de julgamento: Marcelo Fernandez Trindade. j. 10.07.2007. Disponível em: [http://www.cvm.gov.br/sancionadores/sancionador/2007/20070710_RJ20071 079.html]. Acesso em: 10.05.2016.

Extrato da sessão de julgamento do Processo Administrativo Sancionador CVM RJ 24/00. Diretor-Relator: Wladimir Castelo Branco Castro. Presidente da sessão de julgamento: Marcelo Fernandez Trindade. j. 18.08.2005. Disponível em:

[http://www.cvm.gov.br/sancionadores/sancionador/2005/20050818_2400.htm 1]. Acesso em: 15.05.2016.

Extrato da sessão de julgamento do Processo Administrativo Sancionador CVM 09/2004. Diretor-Relator: Pedro Oliva Marcilio de Sousa. Presidente da sessão 
de julgamento: Marcelo Fernandez Trindade. j. 20.06.2006. Disponível em: [http://www.cvm.gov.br/export/sites/cvm/sancionadores/sancionador/anexos/2 006/20060620_PAS_0904.pdf]. Acesso em: 25.04.2016.

Extrato da sessão de julgamento do Processo Administrativo Sancionador CVM 22/1994. Diretor-Relator: Luiz Antonio de Sampaio Campos. Presidente da sessão de julgamento: Luiz Leonardo Cantidiano. j. 15.04.2004. Disponível em: [http://www.cvm.gov.br/sancionadores/sancionador/2004/20040415_2294.htm 1]. Acesso em: 25.04.2016.

Extrato da sessão de julgamento do Processo Administrativo Sancionador CVM 2002/2405. Diretora-Relatora: Norma Jonssen Parente. Presidente da sessão de julgamento: Wladimir Castelo Branco Castro. Relator do voto vencedor: Luiz Antonio De Sampaio Campos. j. 09.10.2003. Disponível em: [http://www.cvm.gov.br/export/sites/cvm/sancionadores/sancionador/anexos/2 003/20031009_PAS_RJ20022405.pdf]. Acesso em: 25.04.2016.

BRASIL. Conselho de Recursos do Sistema Financeiro Nacional. Recurso $n^{o}$ 8253, referente ao Processo Administrativo Sancionador 18/01. ConselheiroRelator: Felisberto Bonfim Pereira. julgado em 27.02.2008. Brasília: Ministério da Fazenda, CRSFN, 2008. Disponível em [http://www.bcb.gov.br/.../download.asp?arquivo=ACÓRDÃO CRSFN 830808.doc]. Acesso em 17.05.2016.

BRASIL. Superior Tribunal de Justiça (STJ). Habbeas Corpus n ${ }^{\circ}$ 8.928/SP Órgão Julgador: Sexta Turma. Relator: Min. Fernando Gonçalves. São Paulo. Publicação no DJ em 24.05.1999, p. 532. 
Extrato da sessão de julgamento do Processo Administrativo Sancionador CVM 35/2000. Diretor-Relator: Wladimir Castelo Branco Castro. Presidente da sessão de julgamento: Marcelo Fernandez Trindade. j. 12.04.2005. Disponível em: [http://www.cvm.gov.br/export/sites/cvm/sancionadores/sancionador/anexos/2 005/20050412_PAS_3500.pdf]. Acesso em: 25.04.2016.

Extrato da sessão de julgamento do Processo Administrativo Sancionador CVM 13/2009. Diretor-Relator: Eli Loria. Presidente da sessão de julgamento: Maria Helena dos Santos Fernandes de Santana. j. 13.12.2011. Disponível em: [http://www.cvm.gov.br/sancionadores/sancionador/2011/20111213_1309.htm 1]. Acesso em: 05.05.2016.

Extrato da sessão de julgamento do Processo Administrativo Sancionador CVM 04/2004. Diretor-Relator e Presidente da sessão de julgamento: Marcelo Fernandez Trindade. j. 28.06.2006. Disponível em: [http://www.cvm.gov.br/sancionadores/sancionador/2006/20060628_0404.htm 1]. Acesso em: 15.05.2016.

Extrato da sessão de julgamento do Processo Administrativo Sancionador CVM RJ 11/2008. Diretora-Relatora: Luciana Dias. Presidente da sessão de julgamento: Otavio Yazbek. j. 21.08.2012. Disponível em: [http://www.cvm.gov.br/sancionadores/sancionador/2012/20120821_1108.htm 1]. Acesso em: 24.05.2016

Extrato da sessão de julgamento do Processo Administrativo Sancionador CVM RJ 2011/3665. Diretora-Relatora: Luciana Dias. Presidente da sessão de julgamento: Maria Helena dos Santos Fernandes de Santana. j. 03.04.2012. Disponível em: 
[http://www.cvm.gov.br/export/sites/cvm/sancionadores/sancionador/anexos/2 012/20120403_PAS_RJ20113665.pdf]. Acesso em: 24.05.2016.

- Regulamentação:

Lei $\mathrm{n}^{\mathrm{o}}$ 6.385, de 7 de dezembro de 1976. Disponível em [http://www.planalto.gov.br/ccivil_03/leis/L6385.htm]. Acesso em 17.05.2016.

Lei $\mathrm{n}^{\mathrm{o}}$ 6.404, de 15 de dezembro de 1976. Disponível em [http://www.planalto.gov.br/ccivil_03/leis/L6404compilada.htm]. Acesso em 17.05.2016.

Lei $\mathrm{n}^{\mathrm{o}}$ 13.105, de 16 de março de 2015. Disponível em [http://www.planalto.gov.br/ccivil_03/_ato2015-2018/2015/lei/113105.htm]. Acesso em 17.05.2016.

Instrução CVM no 31, de 08 de fevereiro de 1984 (revogada pela ICVM 358/02). Disponível em [http://www.cvm.gov.br/legislacao/inst/inst031.html]. Acesso em 17.05.2016.

Instrução CVM n $\mathrm{n}^{\mathrm{o}}$ 358, de 03 de janeiro de 2002. Disponível em [http://www.cvm.gov.br/legislacao/inst/inst358.html]. Acesso em 17.05.2016. 